\title{
LAWS, EDUCATIONAL OUTCOMES, AND RETURNS TO SCHOOLING: EVIDENCE FROM THE FULL COUNT 1940 CENSUS
}

\author{
Karen Clay \\ Jeff Lingwall \\ Melvin Stephens, Jr. \\ Working Paper 22855 \\ http://www.nber.org/papers/w22855 \\ NATIONAL BUREAU OF ECONOMIC RESEARCH \\ 1050 Massachusetts Avenue \\ Cambridge, MA 02138 \\ November 2016
}

Jeff Lingwall's work was supported in part by a grant from the Kauffman Foundation. The authors declare that they have no relevant or material financial interests that relate to the research described in this paper. The views expressed herein are those of the authors and do not necessarily reflect the views of the National Bureau of Economic Research.

NBER working papers are circulated for discussion and comment purposes. They have not been peerreviewed or been subject to the review by the NBER Board of Directors that accompanies official NBER publications.

(C) 2016 by Karen Clay, Jeff Lingwall, and Melvin Stephens, Jr.. All rights reserved. Short sections of text, not to exceed two paragraphs, may be quoted without explicit permission provided that full credit, including $(\subset$ notice, is given to the source. 
Laws, Educational Outcomes, and Returns to Schooling: Evidence from the Full Count 1940

Census

Karen Clay, Jeff Lingwall, and Melvin Stephens, Jr.

NBER Working Paper No. 22855

November 2016

JEL No. I26,J24,J31,N32

\section{$\underline{\text { ABSTRACT }}$}

This paper uses a new dataset on state compulsory attendance, continuation school, and child labor laws with the 1940 full count Census of Population to estimate the returns to schooling for native-born white men in the 1885-1912 birth cohorts. IV estimates of returns to schooling range from 0.064 to 0.079 . Quantile IV estimates show that the returns to schooling were largest for the lowest quantiles, and were generally monotonically decreasing for higher quantiles. These findings suggest that early schooling laws may have contributed to the Great Compression by increasing education levels for white men at the bottom of the distribution.

\author{
Karen Clay \\ Heinz College \\ Carnegie Mellon University \\ 5000 Forbes Avenue \\ Pittsburgh, PA 15213 \\ and NBER \\ kclay@andrew.cmu.edu \\ Jeff Lingwall \\ Truman State University \\ 100 East Normal Avenue \\ Kirksville, MO 63501 \\ jlingwall@truman.edu
}

Melvin Stephens, Jr.

University of Michigan

Department of Economics

341 Lorch Hall

611 Tappan St.

Ann Arbor, MI 48109-1220

and NBER

mstep@umich.edu 


\section{Introduction}

Rising inequality is the subject of ongoing debate and scrutiny. Earnings inequality fell during the Great Compression in the mid-twentieth century United States (Goldin and Margo 1992; Kopczuk, Saez, and Song 2010). The reasons for the decline in inequality include technological, structural, and human capital-related changes in the economy (Goldin and Katz 2008). Within human capital, there were two complementary - and to some degree related - movements that increased educational opportunities. The first was the adoption and refinement of compulsory attendance, continuation school, and child labor laws. Together these laws were initially designed to ensure common or grammar school levels of education, commonly six to eight years, although subsequently these laws required some amount of high school attendance. The second was the high school movement, which offered increasing numbers of older students access to educational opportunities beyond those offered in local common or grammar schools. While there has been considerable focus on the high school movement (Goldin and Katz 2011) and on schooling laws affecting high school attendance (e.g., Acemoglu and Angrist 2000), much less attention has been paid to changes in education below high school. Educational attainment for cohorts affected by these earlier laws is potentially important because of its influence on the lower parts of the educational distribution.

Drawing on the full count 1940 census and a new detailed coding of state compulsory attendance, continuation school, and child labor laws, this paper examines the effects of these schooling laws on educational outcomes and returns to schooling for native-born white men in the 1885-1912 birth cohorts. ${ }^{1}$ These birth cohorts were 27-54 in 1940 and so were at the leading edge of the Great Compression. The coding of the laws takes into account the numbers of years of education required by compulsory attendance, continuation school, and child labor laws taken together. The data on laws builds on work by previous authors (Lleras-Muney 2002 and Goldin

\footnotetext{
${ }^{1}$ This paper is limited to white men both for comparability to much of the prior literature and in recognition of the fact that many institutional factors (e.g., Jim Crow laws, lagging school quality for blacks, and cultural norms against work outside of the home for women) must be carefully addressed to accurately assess the impact of schooling and child labor laws on the economic outcomes of blacks and women. Future work will examine the impact of schooling laws for these groups.
} 
and Katz 2011) by extending the coding of laws back to earlier time periods (pre-1910). For the post-1910 period, we build on the work of Stephens and Yang (2014) by revisiting original session laws and reconciling differences between these sources and the coding of the schooling and child labor laws found in prior studies.

The paper exploits variation in the years of schooling requirements generated by changes in compulsory schooling, continuation schooling, and child labor laws across states over time to estimate the returns to schooling. Specifications are used that account for differential trends across regions of birth to account for the fact that some regions such as the South lagged the rest of the country in adopting these laws (Stephens and Yang 2014). First stage regressions show a statistically significant increase in educational attainment due to the passage of these laws. We find that these early compulsory schooling laws increased completion of six, seven, and eight years of education, which is precisely the range over which the laws would be expected to bind. The effect of having laws requiring seven or eight years of schooling was to increase education by about 0.1 year.

Returns to schooling are estimated using instrumental variables (IV) estimation and by using quantile IV methods to examine the effects of the laws across the weekly wage distribution. Using these laws as instrumental variables, the paper finds positive and significant estimates of the returns to schooling. Quantile IV estimates indicate that the returns to schooling were positive for all but the top of the weekly wage distribution, were largest for the bottom of the distribution, and declined fairly monotonically across the distribution. The results are robust to dropping Southern born men for whom the trend in schooling laws and educational attainment is growing most rapidly (Stephens and Yang 2014). In addition, while the sample is limited to native-born men due to the state of birth based identification strategy, the results are robust for those men with native-born parents.

This paper contributes to the literatures on the effects of school attendance laws on schooling, returns to schooling, and inequality. It extends the previous literature on school attendance by using new detailed coding of state compulsory schooling, continuation schooling, and child labor laws that primarily affect children ages eight to fourteen, using the full count 1940 census, and 
by using both standard and quantile IV methods while accounting for differential regional trends. The results are in line with Lleras-Muney's (2002) results for the 1901-1925 birth cohorts using the 1960 census. They are also in line with Margo and Finegan (1996), who examine older and younger fourteen years olds in 1900; with Eisenberg (1988), who examines Iowa and Pennsylvania; and with Puerta (2011) who uses difference in difference to examine adoption in border townships and counties from 1850-1910.

This paper contributes to the literature on returns to schooling by showing that, for native-born white men in the 1885-1912 birth cohorts, laws that focused on ages eight to fourteen generated positive and significant returns to schooling. The literature on returns to schooling largely focuses on laws affecting later birth cohorts and older ages. For example, Angrist and Krueger (1991) consider the 1920-1949 birth cohorts, Staiger and Stock (1997) consider the 1930-1949 birth cohorts. A few papers have cohorts that overlap with ours. Goldin and Katz (2000) provide OLS estimates for the 1850-1897 birth cohorts in Iowa. Acemoglu and Angrist (2000), Oreopolous and Salvanes (2011) and Stephens and Yang (2014) construct IV estimates for the 1910-1939, 1899-1982, and the 1905-1954 birth cohorts, respectively. This last set of papers span very long time periods, provide average estimates of the return to schooling and are primarily identified by changes in required education for children ages fourteen to eighteen.

This paper also contributes to the literature on inequality. Relatively few papers have examined the returns to schooling across the earnings distribution. Our work is complementary to Goldin and Katz's important work on the high school movement. We examine the effects of laws focused on school attendance of children who were ages eight to fourteen. Our quantile IV estimates suggest that increased educational attainment at the sub-high school level likely contributed to the narrowing of inequality, by increasing wages of individuals at the bottom of the distribution more than individuals at other points in the distribution.

The paper is set out as follows. The next section provides background on the development of compulsory attendance, continuation schooling, and child labor laws in the U.S. as well as trends in education outcomes and economic inequality. The following two sections discuss the data 
and the empirical methodology, respectively. We then turn to a presentation of our empirical results before concluding.

\section{Background}

\section{Compulsory Attendance, Child Labor, and Continuation Schooling Laws}

Compulsory attendance laws commonly stated an age at which students had to begin attending school, an age at which they could leave, and a minimum number of weeks a child had to attend. Initial laws often used ages eight and fourteen as the entry and exit ages, respectively, and these ages were lowered and raised over time. Many states exempted children for a variety of reasons including those who had attended for a certain number of years or those who had completed a specific schooling course (e.g., "the common school course"). Furthermore, numerous states changed these exemptions over time. The online Data Appendix contains examples of the laws.

Compulsory attendance laws were often complemented with child labor laws that exempted working children from full-time school attendance. These labor laws let employed children stop attending school before the exit age found in the compulsory attendance law, usually after the child had attained a certain level of education. Children were typically allowed to leave school to work at age fourteen. A few states had earlier ages, but most of these states later raised the age at which a working child was allowed to leave school. Child labor laws affecting school attendance were one of many different kinds of laws targeting employed children. For example, many states used age-based restrictions for employment in variety of industries, restricted work hours, and regulated working conditions in a variety of ways. This paper focuses on child labor laws that exempted children from full-time school attendance.

States often required these working children to attend continuation school, meaning part-time or evening school that supplemented their employment. Like the compulsory attendance laws, continuation school laws required attendance until a certain age, and often exempted children with a certain number of years of education. 
Figure 1 shows when initial compulsory attendance laws, child labor laws affecting school attendance, and continuation schooling laws went into effect across the U.S. states. The first compulsory attendance law was passed in Massachusetts in $1852 .^{2}$ Attention to and debate about schooling heightened in 1871, as the Republican Party kicked off a "public school crusade." 3 By 1900 almost all states outside the South had schooling laws and by 1920 every state had a compulsory attendance law. ${ }^{4}$ Following the enumeration of the 1900 Census, public awareness that one-quarter of children were employed led to a flurry of state level child labor reforms (Puerta 2011). As child labor laws were revisited, they began to integrate with compulsory attendance laws, such as exempting working children from school attendance in some states. Relatedly, while only a handful of states had continuation school laws before 1911, this number increased rapidly in the late 1910s due to the vocational education requirements of the SmithHughes Act of 1917 and additional public focus on child labor following World War I (Mayman $1933)^{5}$

\section{Educational Outcomes}

Figure 2 shows the trends in self-reported years of schooling for native-born white males from the 1940 complete count census for the 1876-1912 birth cohorts. Educational attainment was trending up throughout the education distribution. By the 1912 birth cohort, more than 80 percent of respondents reported completing eight years of schooling, and many individuals reported at

\footnotetext{
${ }^{2}$ We differentiate compulsory attendance laws from the variety of compulsory instruction laws that dated back to colonial times. For example, colonial instruction laws tasked town selectmen to ensure parents were raising literate children but did not mandate school attendance. See Cook (1912) and Ensign (1921).

${ }^{3}$ See McAfee (1998).

${ }^{4}$ Although 1918 is the traditional date for the passage of the last compulsory attendance law (in Mississippi), it was not until 1920 when all the Southern states had non-local option laws. See the online Data Appendix for further notes on county option laws and statewide adoption. For simplicity, the District of Columbia will be referred to as a state.

${ }^{5}$ Continuation schooling laws were of two types: either mandating that districts provide these schools (typically upon reaching a minimum number of eligible students threshold) or giving districts the option of setting up these schools and requiring attendance. Goldin and Katz (2002) combine both types of laws in their empirical analysis and designate such laws as "permissible." Following their approach, the analysis in this paper uses "permissible" continuation schooling laws. The Smith Hughes Act required "... that at least one-third of the sum appropriated to any state for the salaries of teachers of trade, home economics, and industrial subjects shall, if expended, be applied to part-time school over fourteen years of age who have entered upon employment."
} 
least nine years of schooling. The effect of the high school movement is evident beginning around the 1900 birth cohort.

Even allowing for some inflation of self-reported schooling, it is clear that the laws were unlikely to have been binding for most children. ${ }^{6}$ The majority of children in the earliest cohorts were already completing between six and eight years of schooling, which were the typical numbers of years that students would complete by age fourteen. Relatively high schooling levels even with voluntary attendance is consistent with historical evidence that laws were only passed after most children were already attending school (Landes and Solmon 1972; Clay, Lingwall, Stephens 2012).

\section{Economic Inequality}

A number of sources including Goldin and Katz (1999, 2001, 2008), Kopczuk, Saez, and Song (2010), and Lindert (2000) present detailed evidence on the decrease and then increase in earnings inequality over the course of the twentieth century. Skill ratios fell in manual trades from 1907 to 1929. Wage differentials in manufacturing declined across most industries between 1890 and 1940, as did the ratio of clerical worker wages to production workers. The ratio of white collar to blue collar earnings fell from 1910 to 1960. The 1940s in particular experienced a dramatic reduction in income inequality, earning the moniker "The Great Compression" (Goldin and Margo 1992).

Goldin and Margo show that earnings differentials between white and blue-collar workers decreased throughout the 1940s and 1950s. An increase in the supply of highly educated workers was central to the compression. In the 1940s, the demand for high-school educated white males relative to those without a high school education was lower than during any of the following three decades. More importantly, the supply of college graduates increased substantially after the war, lowering the relative price for college-level skills.

\footnotetext{
${ }^{6}$ As Goldin (1999) notes, respondents were not always accurately reporting educational attainment.
} 
These large post-war effects were preceded by pre-war wage compression among blue-collar workers beginning as early as the 1920s. As we will show, increased returns to schooling for these workers at the bottom of the wage distribution appear to have been one factor in the decline in inequality. For some native-born white males, schooling laws, especially those focused on primary school attendance, appear to have caused them to attend school longer than they might have in the absence of the laws. To the extent this raised their earnings, school laws may have contributed to a decrease in earnings inequality.

\section{Data}

\section{Attendance, Child Labor, and Continuation Schooling Laws}

Data on compulsory attendance laws, child labor laws, and continuation schooling laws were gathered from the session laws of individual states. This new database captures each compulsory attendance age limit, years of schooling exemption, child labor exemption, continuation school requirement, and continuation school exemption in force in each state and year from 1880 to 1930. Our work builds on prior compilations in the United States Bureau of Education (various years), Goldin and Katz (2002), Lleras Muney (2002), Moehling (1996), Eisenberg (1988), and Stephens and Yang (2014). It is worth noting that states were only coded as having a law once the law covered all counties or required counties to specifically opt-out. This issue arises, because a number of Southern states passed laws merely permitting counties to enact compulsory attendance. Few counties actually made use of this law and passed compulsory attendance laws. These opt-in states later passed universal laws that covered all counties. In a few cases, the laws permitted counties to vote to opt-out of the law. In this coding convention, the year of passage for some states is later than dates conventionally used in the literature. ${ }^{7}$ The dataset attached in the online Data Appendix provides the dates, requirements, and original source for each law.

\footnotetext{
${ }^{7}$ For conventional dates of initial laws, see Department of Education, National Center for Educational Statistics, Digest of Education Statistics, 2004. We differ from the prior literature in coding these initial laws: Alabama (1917 rather than 1915 due to when the law went into effect); Arizona (1875 rather than 1899, due to passage, then repeal, then re-passage of the law); Arkansas (1917 rather than 1909 due to limited geographic applicability of the 1909 law); Florida (1919 rather than 1915 due to "opt in" laws); Georgia (1917 rather than 1916 due to when the law went into effect); Louisiana (1916 rather than 1910 due to limited geographic applicability of the 1910 law); Mississippi (1920 rather than 1918 due to "opt in" laws); North Carolina (1913 rather than 1907 due
} 
We follow Stephens and Yang (2014) and calculate the years of required attendance for each state-year birth cohort. By using an iterative process that calculates whether attendance was required at each year of life, based on the age limits and exemptions in place in that year, we derive the cumulative years each child was required to be in school. The online Data Appendix describes the steps in this calculation, showing the interaction between the various exemptions and age limits regulating attendance. Continuation schooling requirements are determined similarly. Assuming children entered school at the required age, attended each required year, left to work once possible, and attended continuation school when required, this calculation gives the number of years each child was obligated to attend.

Figure 3 plots the average number of years of required schooling by year of birth for compulsory school attendance laws and for the combination of school attendance and continuation schooling laws. Here, and in the main results, we treat compulsory school attendance and continuation schooling laws together, as these laws formed part of the same comprehensive regulatory scheme for the education of children. Continuation schooling laws complemented work permit laws that excused working children from full-time school attendance, and often required part-time attendance through the exact age limits faced by unemployed children. However, we also present results that consider compulsory attendance and continuation laws separately. These additional estimates show that continuation schooling laws only affected having more than eight years of schooling, consistent with the margins on which these laws most likely would have influenced educational attainment.

to "opt in" laws); South Carolina (1919 rather than 1915 due to "opt in" laws); Tennessee (1913 rather than 1905 due to county-by-county rollout of the laws); Texas (1916 rather than 1915 due to when the law went into effect, ignoring an earlier temporary compulsory attendance law enacted during the 1870s); Virginia (1918 rather than 1908 due to "opt in" laws); and Washington (1886 rather than 1871 due to repeal of the 1871 law in 1873, and limited applicability of the following 1877 law). See the online Data Appendix for further discussion, and the dataset attached in the online Data Appendix for complete sources. 


\section{Educational and Work Outcomes}

The data are from the 1940 Preliminary Complete Count Census of Population Data available from IPUMS USA (Ruggles et al 2015). The census contains information on individuals' sex, race, state of residence, state of birth, and age. Information on parental birthplace is available for sample line individuals. The sample line is a five percent random subset of individuals in the 1940 Census for whom an additional set of questions was asked relative to the remaining population. Given the focus on returns to schooling in this paper and for comparability for with much prior research, the sample is limited to native-born white males, leaving a sample size of roughly 20 million. $^{8}$ The census also contains information on highest grade attended and on wage income, but not on income from self-employment. Table 1 gives summary statistics for the sample.

The analysis of educational outcomes draws on retrospective data on years of schooling from the 1940 Census which was the first census to ask about years of completed schooling and income. Individuals were asked to report the highest grade completed. As Goldin (1999) notes, they were not always reporting accurately. "I have recently demonstrated that the 1940 census greatly overstates the proportion of Americans who were high school graduates." 9 To anticipate our estimation strategy, if we assume the proportion of people in a given state overstating their education is either constant or trending similarly within a region, the overstatement should have limited impact on estimates of the effect of compulsory attendance laws on schooling outcomes. We return to this issue in section 4 .

Our sample covers the 1885-1912 birth cohorts, who were 27-54 at the time of the 1940 Census. ${ }^{10}$ This age restriction is intended to capture prime age working men and exclude older men who might be retired or working part time. Our initial estimates of the impact of schooling laws on educational attainment include all men in this age range, regardless of work status.

\footnotetext{
${ }^{8}$ Future work will examine the effects of these laws and other educational policy interventions by race and gender.

${ }^{9}$ Goldin (1999), p. S67.

${ }^{10}$ Year of birth is calculated as 1940-age-1, because the census was taken in April and most individuals had not yet had their birthday. The 1940 Census does not include quarter of birth information that can be used to more accurately compute year of birth in other Censuses.
} 
To estimate the returns to schooling, some additional restrictions were imposed. First, we create a "working men" sample, which we limit to those who report both positive earnings and positive weeks worked in 1939. Second, due to the relatively high levels of agricultural employment during this period, including working on one's own farm, earnings may be understated for a nonnegligible subset of men. This is because the 1940 Census did not collect information on selfemployment income. As such, we create a sample of "restricted working men" which further requires that the men worked at least 40 weeks in 1939, worked but were not self-employed, and did not live on a farm. Summary statistics for these samples are presented in Table 1.

The dependent variable in our returns to schooling specifications is the log of weekly wages. The weekly wage is the ratio of annual wage and salary income to annual weeks worked, both of which are measured for the prior calendar year (1939). Following Acemoglu and Angrist (2000), annual earnings are censored at the 98th percentile, and values above the 98th percentile are replaced with 1.5 times the 98th percentile value.

\section{Empirical Methodology}

Our main specification for estimating the returns to schooling is

$$
w_{i s c}=\beta_{0}+\beta_{1} E d u c_{i s c}+\gamma_{s}+\alpha_{s c}+\varepsilon_{i s c}
$$

where $w_{i s c}$ is the $\log$ weekly wage of individual $i$, born in birth cohort $c$, and in state $s, E d u c_{i s c}$ is their years of education, $\gamma_{s}$ is a vector of state fixed effects, and $\alpha_{s c}$ is a vector of birth cohort fixed effects for each of the four census regions. All estimates have standard errors clustered at the state-cohort level.

OLS estimates of equation (1) are typically regarded as being inconsistent, since years of schooling is generally considered to be a choice variable that is likely correlated with the error term in the weekly wage equation. E.g., more motivated individuals tend to stay in school longer and, to the extent that motivation leads to higher levels of productivity, are paid more by employers. As such, specifications such as equation (1) are typically estimated using empirical 
methods that account for the endogeneity of education (e.g., Card 1999).

This paper uses an instrumental variables (IV) strategy to estimate the returns to schooling using years of required schooling, based on state and year of birth, as an instrumental variable for reported educational attainment. Our first stage specification is

$$
E_{d u c_{i s c}}=\pi_{0}+\pi_{1} \text { LawYears }_{s c}+\theta_{s}+\tau_{s c}+u_{i s c}
$$

where $E d u c_{i s c}$ is the educational attainment of individual $i$, born in birth cohort $c$, and in state $s$, $L a w Y e a r s_{s c}$ is the years of required attendance for someone born in state $s$ in birth cohort $c, \theta_{S}$ is a vector of state fixed effects, and $\tau_{s c}$ is a vector of birth cohort fixed effects for each of the four census regions.

We estimate specifications where LawYears is a continuous variable and specifications where the laws are specified as a set of indicator variables. We use indicator variables because the effect of requiring one more year of schooling may not be linear throughout the distribution of required years of schooling. One to five years of required schooling are grouped together into a single dummy variable, because this primarily captures the initial adoption of laws. Older children at the time the laws are adopted may be subject to a just one or two years of required attendance. Separate dummy variables are included for six, seven, eight, and nine or more years of required schooling. ${ }^{11}$ The distribution of required schooling is also presented in Table 1.

The effects of the laws are identified by variation in the timing of various statutes within state and region over time. Region by year of birth cohort fixed effects are included so the counterfactual is that the changes in state educational outcomes would have been the same as other states in the same region. This is the specification used in Stephens and Yang (2014), which examines educational outcomes in more recent Censuses. It is also similar to LlerasMuney (2002) and Goldin and Katz (2011) in using retrospective census data and including state

\footnotetext{
${ }^{11}$ Of the over 1.1 million observations in the nine or more years category, over 96 percent are required to attend school for nine years while the remainder have a ten year requirement.
} 
and cohort fixed effects and regional controls.

A significant concern in the literature is that laws are being passed and educational outcomes are rising, but the laws are not causing educational outcomes to rise. This is central to Landes and Solmon's (1972) critique and has been investigated by other authors, notably Lleras-Muney (2002). Our estimation approach is designed to address this endogeneity by including both state fixed effects and region-cohort effects, so changes within state over time are identifying effects and states are being compared to other states in their region.

\section{Results}

\section{Impact of Laws on Educational Attainment}

Table 2 presents the results of the continuous and categorical estimates of years of required schooling on educational outcomes. The Table uses three samples: i) all native-born white men, ii) native-born white men who reported positive earnings and positive weeks worked in the prior year ("working men" sample), and iii) a restricted sample which also excludes the selfemployed, those who lived on a farm, and those who worked less than 40 weeks in 1939 ("restricted working men" sample). For each sample, two specifications of the laws are used. The first uses a continuous measure of required years of schooling calculated based on the prevailing compulsory attendance, child labor, and continuation school laws. The second specification replaces the continuous measure with a set of indicators for the level of required schooling.

The effect of years of required schooling, measured continuously (columns 1, 3, and 5 of Table 2 ), is positive, statistically significant, and similar across the three samples. However, when we specify the years of required schooling using a set of indicators (columns 2, 4, and 6), the

relationship between schooling requirements and educational attainment is non-linear. Relative to having no required years of schooling, the effects of being required to attend one to five years of schooling and then moving to six required years are somewhat modest. However, a substantial increase in educational attainment is observed when the schooling requirement is 
increased to seven years, followed by a modest increase in education when moving to an eight year minimum before another large observed jump in acquired schooling when the requirement is further raised to nine or more years.

Figure 4 provides detail of where the schooling laws impacted the education distribution. The Figure shows results from regressing the categorical law variables on a series of binary outcomes for whether the individual completed at least $X$ years of schooling, where $X$ is shown in the horizontal axis. Thus, the Figure shows the impact of the laws on one minus the education CDF. Full results are presented in Appendix Table 1. Each line in the Figure shows the effect for a given categorical variable, while the estimates found at each point on the horizontal axis represents the results from a different regression.

The results in Figure 4 show that laws requiring six, seven, and eight years of schooling increase the number of individuals reporting they completed six, seven, or eight years of schooling. There are much smaller effects for lower and higher levels of reported education. This is what we would expect if the laws were binding. Laws requiring nine or more years of schooling increase the number of individuals who reported completing nine or ten years of schooling. Laws that only resulted in between one and five years of required education, mainly for cohorts in their pre-teenage years when the laws were adopted, have less of an effect. ${ }^{12}$

Table 3 summarizes the literature on the effects of compulsory attendance and related laws on educational outcomes. Similar to many - although not all - previous papers, our analysis finds statistically significant but small effects of laws. This paper differs from previous papers in that it uses a larger census sample, a more detailed coding of the laws regarding years of required

\footnotetext{
${ }^{12}$ Appendix Figure 1 provides similar graphs that treat the requirements of compulsory attendance and child labor laws separately from those of the continuation school laws. The point estimates along with their standard errors are shown in Appendix Table 2. For compulsory attendance and child labor laws in Panel A of Appendix Figure 1, the pattern is similar to Figure 4. For continuation school in Panel B, one to two years required attendance has only small effects at any level of completed schooling, while three to four years required attendance has large effects on completion of nine to ten years of schooling, as expected from laws that often sought to provide some form of postprimary education for working teenagers. Goldin and Katz (2011) also find significant effects of continuation school laws on educational attainment after accounting for compulsory schooling and child labor laws.
} 
schooling, a more flexible specification for estimating the effects of years of required schooling on reported schooling, and somewhat earlier birth cohorts.

\section{Estimates of the Returns to Schooling}

Table 4 presents OLS and IV estimates of the returns to schooling for the two groups of working men reported in Table 2: the working men sample (native-born white men who reported positive earnings and weeks worked last year) and the restricted working men sample (native-born white men who reported positive earnings, worked at least 40 weeks in 1939, working but were not self-employed, and did not live on a farm). ${ }^{13}$ Each regression includes state of birth and region by year of birth fixed effects. The first stage F-statistics, testing the joint null hypothesis for the excluded instruments, are shown at the bottom of the table. ${ }^{14}$ All of the F-statistics exceed conventional levels. The OLS estimates of the returns to schooling (columns 1 and 4) are quite comparable to those found for similar specifications in subsequent Census years (Acemoglu and Angrist 2000; Stephens and Yang 2014).

Given that the results in Table 2 indicate that the estimated impact of schooling laws on educational attainment depends upon whether required schooling is specified as continuous or categorical, we present results using both specifications of the instrument in Table 4. When a continuous measure of schooling is used as the instrumental variable (columns 2 and 5), we find estimated returns to schooling that are on the high side of prior estimates. Returns are approximately $16 \%$ and $12 \%$, and are roughly twice as large as the corresponding OLS estimates. When schooling laws are allowed to have a non-linear relationship with educational attainment (columns 3 and 6), we find estimated returns to schooling that fit in the range of prior estimates. Returns are approximately $8 \%$ and $6 \%$ and are quite similar to the corresponding OLS estimates.

\footnotetext{
${ }^{13}$ There is a modest impact of schooling on employment outcomes as reported in Appendix Table 8. Following the prior literature, we do not implement sample selection corrections when estimating wage equations for prime age white males.

${ }^{14}$ The first stage regressions are shown in Table 2.
} 
To gain insight into why the IV estimates differ dramatically depending on the specification of required schooling (continuous vs. categorical) in the first stage, it is helpful to decompose the IV estimator. When using a single instrumental variable, it is well-known that the IV estimator, $\hat{\beta}^{I V}$, is equivalent to

$$
\hat{\beta}^{I V}=\frac{\hat{\delta}}{\hat{\pi}}
$$

In the current context, $\hat{\delta}$ is the reduced form estimated coefficient from regressing the log weekly wage on required years of schooling, and $\hat{\pi}$ is first stage estimated coefficient on required years of schooling. Angrist and Imbens (1995) show that specifying a single instrumental variable as a set of $K$ mutually exclusive indicators, the IV estimator can be written (in the current context) as

$$
\hat{\beta}^{I V}=\sum_{k=1}^{K} \mu_{K} \frac{E[w \mid \text { LawYears }=k]-E[w \mid \text { LawYears }=k-1]}{E[\text { Educ } \mid \text { LawYears }=k]-E[\text { Educ } \mid \text { LawYears }=k-1]}
$$

where $\mu_{K}$ are a set of weights, each of which lies between zero and one, inclusive, and collectively sum to one. Thus, the IV estimator is a weighted average of a set of Wald estimators where each Wald estimate is the estimated return from required years of schooling increasing from $k-1$ to $k .^{15}$

To evaluate the IV estimators using the above equations, we also need to examine the corresponding reduced form estimates, which are shown in Appendix Table 3. A cursory examination of the reduced form results appears to yield similar effects of the laws on the log weekly wage. For the working men sample, the continuous instrument specification (column 1) indicates that raising required schooling from zero years to nine years would increase the log weekly wage by $0.0035 * 9=0.0315$. An examination of the categorical specification yields a comparable estimate of the impact of having nine years of required schooling relative to zero years of 0.038 .

\footnotetext{
${ }^{15}$ Our regression specification does not yield direct estimates of the numerator and denominators of the Wald Estimates in equation (4). However, the differences between the expected values in (4) can be replaced with differences in our estimated parameters for the impact of increasing required schooling from $k-1$ to $k$ years. Thus, for expositional purposes, we frame our discussion in terms of equation (4). For a decomposition of the IV estimator that directly uses our estimated parameters, see Angrist (1988).
} 
The categorical reduced form coefficients, upon closer inspection, reveal a non-linear path between zero and nine required years of schooling. For example, the reduced form coefficients actually decline (slightly) between six and seven required years of schooling while doubling in size between the one to five year and six year categories (column 2 of Appendix Table 3). Essentially the opposite pattern occurs with the first stage coefficients (column 4 of Table 2). Angrist and Imbens (1995) note that the weight, $\mu_{K}$ received by a given Wald estimate in the computation of $\hat{\beta}^{I V}$ is proportional to the denominator of that Wald estimate. In other words, the changes in $k-1$ to $k$ that receive the largest weight are the ones exhibiting the largest incremental increase in the first stage. As the largest first stage changes occur from six to seven years, which has a slightly negative corresponding reduced form, and from eight to nine years, which has a large positive corresponding reduced form, it is easy to see why different specifications of the instrument in the first stage (continuous vs. categorical) can lead to substantially different IV estimates.

We present results using both the continuous and categorical specifications of required schooling throughout most of the remainder of the paper for comparative purposes. Fortunately, our substantially large sample does not constrain us to use a continuous specification for the instrument in the first stage. Given the potentially large misspecification issues that may arise when using the continuous specification, our preferred estimates are the ones in which we use a categorical specification for required schooling in the first stage.

As a point of comparison, in Appendix Table 4 we present estimates of the impact of laws on educational attainment and the returns to schooling using the previously available $1 \%$ public use micro sample of the 1940 Census (Ruggles et al 2015). The first stage F-statistics are far below conventional levels which requires adjusting the resulting confidence interval for the use of weak instruments. ${ }^{16}$ Although the point estimates are broadly consistent with the findings in Tables 2 and 4 for the working men sample, the resulting confidence intervals are very broad. In particular, the results using the $1 \%$ Census sample are too imprecise to untangle the dramatic

\footnotetext{
${ }^{16}$ Since the schooling law instruments are "weak" when using the $1 \% 1940$ Census sample, the confidence intervals for the IV estimates are constructed using Moreira's (2003) conditional likelihood ratio test. These confidence intervals are computed using version 1.0.7 of the -rivtest- command for Stata (Finlay and Magnusson 2009).
} 
difference in the estimated returns to schooling when using the continuous vs. the categorical specification of the instrumental variable.

Figure 5 shows returns to schooling across the distribution of (log) weekly wages by plotting the results of quantile IV regressions for every fifth quantile using a 25 percent random subset of the working men sample. ${ }^{17}$ Panel A of Appendix Table 5 shows the complete set of quantile IV results for this sample. The instruments are the required years of schooling categorical variables used in Table 4, columns 3 and 6. The returns to schooling are positive across the weekly wage distribution and are largest for the bottom half of the distribution. The returns are relatively flat at about 0.15 for the $5^{\text {th }}$ to the $45^{\text {th }}$ quantiles, decline monotonically to the $80^{\text {th }}$ quantile, and remain roughly constant near zero throughout the rest of the distribution. The substantially larger estimates for those at the bottom of the earnings distribution indicates that the laws played a role in reducing income inequality as measured in the 1940 Census. ${ }^{18}$ In addition, since the wage structure recorded in the 1940 census was typical of the years before World War II, larger returns to schooling for those in the lowest quantiles of the earning distribution may help explain the pre-1940 decrease in skilled versus unskilled blue-collar inequality noted in Goldin and Margo (1992).

Table 5 summarizes the literature on the returns to schooling. In contrast to some papers and consistent with others, this paper finds positive and significant returns to schooling. This paper differs from previous papers in that it uses a larger census sample, a more detailed coding of the laws regarding years of required schooling, a more flexible specification for estimating the effects of years of required schooling on reported schooling, and earlier birth cohorts. It also differs in its focus on the quantile IV.

\footnotetext{
${ }^{17}$ A 25 percent random subset of the working men sample, which still contains over 3.3 million observations, is the largest sample for which we could implement the computationally intensive quantile IV estimator on the restricted access server housing the complete count census. The first stage, OLS, and IV estimates shown in Appendix Table 7 for the 25 percent random sample are quite comparable to those for the full working men sample found in Tables 2 and 4.

${ }^{18}$ Chernozhukov and Hansen (2008) use quantile IV to estimate the returns to schooling across the weekly wage distribution of the using quarter of birth as an instrument and the Angrist and Krueger (1991) sample from the 1980 Census. They find the returns to schooling are rapid declining up to the $40^{\text {th }}$ quantile, decline somewhat more through the $60^{\text {th }}$ quantile and are relatively flat beyond that.
} 
A relevant comparison for these findings is the recent paper by Stephens and Yang (2014) which uses white men in similar age ranges from the 1960-1980 Censuses but finds insignificant, and even wrong-signed, estimates of the returns to schooling. One possible reconciliation of these seemingly disparate sets of findings is that birth cohorts examined in the current paper were affected along different margins than those examined by Stephens and Yang. As is shown in

Figure 4, for the 1885-1912 birth cohorts examined in this paper, the schooling laws primarily had an impact at later stages of common school in years six to eight. Indeed, none of the Southern U.S. states had compulsory schooling laws for the oldest of these birth cohorts while the youngest birth cohorts experienced laws in virtually all states. For the 1905-1954 birth cohorts examined by Stephens and Yang, compulsory schooling was in place for nearly every birth cohort, and most of the adjustments to schooling laws affected education at higher levels of school.

\section{Effects of Native-Born and Foreign-Born Parents}

The historical literature (Tyack 1974, Ralph and Rubinson 1980) and a recent paper by LlerasMuney and Shertzer (2015) raise questions about the extent to which laws were binding for children with foreign-born parents and for foreign-born children. Lleras-Muney and Shertzer examine the impact of contemporaneous schooling and child labor laws on children ages six to sixteen using the 1910-1930 Censuses. They estimate the effects of the laws on enrollment and employment for three groups: native-born children with native-born parents, native-born children with at least one foreign-born parent, and foreign-born children. The effects of the laws are larger for foreign-born children than for either of the two native-born children groups and were nearly identical for both native-born groups of children. Our identification strategy, which uses state of birth to examine the impact of schooling and child labor laws on adult outcomes, only allows us to distinguish between the two native-born groups. We exclude the foreign-born from our analysis.

Parental birthplace is only available for sample line individuals - the 5 percent of the Census who answered the long form questionnaire. Following Lleras-Muney and Shertzer, we divide the 
sample line into two groups: those for whom both parents are native-born and those who have at least one foreign-born parent.

Table 6 uses parental birthplace information to examine whether the impact of schooling and child labor laws on educational attainment differs between those with native-born parents and those with foreign-born parents. Column 1 of the Table shows the effect of the continuous required schooling measure on educational attainment for the all men sample, shown previously in column 1 of Table 3, as a point of comparison. When restricting the sample to only those men who are sample line individuals (column 2), a reduction in the sample size by 95 percent, the estimated impact is unaffected. ${ }^{19}$ The effect of having at least one foreign-born parent reduces educational attainment by over one half of a year (column 3), but the inclusion of this indicator does not affect the estimated impact of schooling and child labor laws on years of schooling.

The final three columns of Table 6 allow for the laws to have different effects on sample line individuals with native-born parents and those with foreign-born parents. Column 4 includes an interaction between required years of schooling and the foreign-born parent indicator. The point estimate on this interaction indicates there is no difference in the impact of schooling laws on educational attainment between those native-born white men with native-born parents and those with foreign-born parents. While this finding lines up with the results in Lleras-Muney and Shertzer (2015) discussed above, the standard error on the interaction term is relatively large in magnitude.

Columns 5 and 6 of Table 6 show the results of separately estimating the effects of the laws for individuals with foreign-born and native-born parents. Relative to the specification in column 4, separating the sample allows the state and region-year of birth effects to differ between these two groups. The coefficient on years of schooling is positive and significant in both columns but is only marginally significant for individuals with foreign-born parents. It is worth noting that the standard errors on the required schooling estimates are large enough to encompass the point estimate of the other group, especially for those with a foreign-born parent. However, when

\footnotetext{
${ }^{19}$ Although the sample size falls by a factor of twenty between columns (1) and (2), the corresponding standard errors fall by less than the square root of 20 because the standard errors are clustered in both columns.
} 
using the categorical specification of required years of schooling, as shown in Appendix Table 6, the estimates are only positive and significant for those with native-born parents. For those with a foreign-born parent, the regressions yield insignificant and, in many cases, results that are opposite in sign than expected. Overall, the results consistently show that schooling laws increased educational attainment of native-born men with native-born parents while the findings for native-born men with a foreign-born parent are more tenuous.

Given our mixed findings for the impact of required schooling on native-born men with foreignborn parents in Table 6 and Appendix Table 6, Table 7 provides returns to schooling for three samples: i) all native-born white men in the sample line, ii) all native-born white men in the sample line with an indicator for having a foreign-born parent, and iii) only native-born white men with native-born parents in the sample line. In Table 7, the continuous required schooling measure yields much higher estimates of the returns to schooling than specifying the laws using categorical measures.

Comparing the estimates using the categorical instruments (columns 3 and 6 in Table 7) across the three samples, two things are notable. First, the F-statistics for native-born white men with native-born parents are larger. This finding is perhaps not surprising given the insignificant estimates on the interactions between the laws and the foreign-born parent indicator. Second, the returns to schooling for native-born white men with native-born parents (Panel $\mathrm{C}$ of Table 7) are generally higher. These results suggest that the returns to schooling from increasing required schooling are larger for those with native-born parents, although the standard errors shown in Panel $\mathrm{C}$ are large enough to include the point estimates from using all sample line white men.

Figure 6 shows the results of using quantile IV to estimate the returns to schooling across the distribution of log weekly wages for both sample line individuals and for those sample line individuals with only native-born parents. The corresponding point estimates and standard errors are shown in Appendix Table 5, Panels B and C. The returns to schooling follow patterns similar to that of the full sample in Figure 5 with higher returns for the lower weekly wage quantiles. As with the IV estimates shown in Table 7, the quantile IV estimates are larger for native-born men 
with native-born parents than for the full sample of native-born men. However, the estimates are not precise enough to draw statistically significant distinctions between these two samples.

\section{Effects for Non-Southern Born Men}

Stephens and Yang (2014) show that the estimated returns to schooling in the 1960-1980 Censuses for white men becomes statistically insignificant and, in some cases, negative in sign when allowing the year of birth fixed effects to vary by Census region. They suggest that the rapid catching up of the South in terms of schooling requirements and school quality, amongst other things, yields the positive and significant estimates of the returns to schooling when not allowing the fixed effects to vary by region. Due to their findings, the specifications used throughout this paper include region by year of birth fixed effects.

Nonetheless, one concern is that the South alone might be driving the results because of its rapid adoption of compulsory attendance laws during this time period. Table 8 re-estimates the first stage regressions in Table 2 but excludes men born in the South. The estimated coefficients on the continuous required schooling measure in columns 1, 3, and 5 are slightly smaller than in Table 2. The estimated coefficients on the categorical required schooling variables in columns 2 , 4 , and 6 are generally smaller and in some cases are no longer significant. This reflects the fact that the variation within and across states is now smaller. The coefficients on eight years of schooling and nine or more years of schooling remain positive and significant. The magnitudes of the coefficients for eight years range from 0.063 to 0.083 , whereas in Table 2 they ranged from 0.123 to 0.138 .

Table 9 re-estimates the OLS and IV returns to schooling regressions in Table 4, but excludes men born in the South. The F-statistics are somewhat lower than those found in Table 4, but still range between 19 and 23, well above the conventional levels. The IV estimates using the categorical laws in columns 3 and 6 are slightly lower than those in Table 4, which includes 
Southern born men, but are well within the earlier confidence intervals. ${ }^{20}$ Thus, excluding Southern born has no qualitative impact on the findings presented earlier.

\section{Conclusion}

This paper contributes to the literature on the effect of schooling laws and returns to schooling for native-born white men born in the late nineteenth and early twentieth centuries. Relative to the prior literature, it uses the full count 1940 census, a more detailed coding of schooling laws, a more flexible specification for estimation, earlier birth cohorts, and quantile IV estimates of returns to schooling. Using compulsory attendance, continuation schooling, and child labor laws as instruments for schooling, the results find positive and significant returns to schooling for native-born white men. Quantile IV results show schooling increased wages for those at the bottom of the earnings distribution relative to higher earners. The findings are similar if we restrict the sample to men with native-born parents or drop men born in Southern states. This paper is limited to white men primarily for comparability to the prior literature, and future work will extend this analysis to include women and blacks. Moreover, numerous additional institutional factors (e.g., Jim Crow laws and lagging school quality for blacks and cultural norms against work outside of the home for women) must be carefully addressed to accurately assess the impact of schooling and child labor laws on the economic outcomes of these groups.

\section{$\underline{\text { References }}$}

Acemoglu, Daron and Joshua Angrist (2000). "How Large Are Human-Capital Externalities? Evidence from Compulsory attendance Laws." NBER Macroeconomics Annual 15: 9-59.

Angrist, Joshua D (1988). "Grouped Data Estimation and testing in Simple Labor Supply Models," Industrial Relations Section Working Paper no. 234.

\footnotetext{
${ }^{20}$ As found throughout the paper, the IV estimates of the returns to schooling using the continuous specification of the laws (columns 2 and 5 in Table 9) are larger than the estimates from using the categorical specification (columns 3 and 6).
} 
Angrist, Joshua D., and Alan B. Keueger (1991). "Does compulsory school attendance affect schooling and earnings?.” The Quarterly Journal of Economics 106.4: 979-1014.

Angrist, Joshua D., and Guido W. Imbens (1995) "Two-Stage Least Squares Estimation of Average Causal Effects in Models with Variable Treatment Intensity," Journal of the American Statistical Association, 90:430, 431-442.

Card, David (1999). "The Causal Effect of Education on Earnings," in the Handbook of Labor Economics, Volume 3, Part A, eds. Orley Ashenfelter and David Card: North Holland.

Chernozhukov, Victor and Christian Hansen (2006). "Instrumental quantile regression inference for structural and treatment effect models," Journal of Econometrics 132:491-525.

Chernozhukov, Victor and Christian Hansen (2008). "Instrumental Variable Quantile Regression: A Robust Inference Approach,” Journal of Econometrics 142:379-398.

Cook, W.A. (1912). "A Brief Survey of the Development of Compulsory Education in the United States," The Elementary School Teacher Vol. 12, 331.

Eisenberg, M. J. (1988). “Compulsory attendance legislation in America, 1870-1915.” PhD Dissertation, University of Pennsylvania.

Ensign, Forest Chester (1921). "Compulsory School Attendance and Child Labor: A Study of the Historical Development of Regulation Compelling Attendance and Limiting the Labor of Children in a Selected Group of States." PhD Dissertation, Columbia University.

Finlay, Keith and Leandro Magnusson. (2009). "Implementing Weak Instrument Robust Tests for a General Class of Instrumental Variables Models," Stata Journal, 9(3):1-24.

Goldin, Claudia (1999). "Egalitarianism and the Returns to Education during the Great Transformation of American Education.” Journal of Political Economy 107, S65. 
Goldin, Claudia and Lawrence Katz (1999). "Human Capital and Social Capital: The Rise of Secondary Schooling in America, 1910-1940." Journal of Interdisciplinary History 29:683-723.

Goldin, Claudia and Lawrence Katz (2000). "Education and Income in the Early 20th Century: Evidence from the Prairies." Journal of Economic History 60:782-818.

Goldin, Claudia and Lawrence Katz (2001). "Decreasing (and then Increasing) Inequality in America: A Tale of Two Half Centuries." In The Causes and Consequences of Increasing Inequality, ed. Finis Welch, 37-82. Chicago: University of Chicago Press.

Goldin, Claudia and Lawrence Katz (2002). Data Appendix to "Mass Secondary Schooling and the State: The Role of State Compulsion in the High School Movement”, 2002. Revised 2007.

Goldin, Claudia and Lawrence Katz (2008). The Race Between Education and Technology. Cambridge: Harvard University Press.

Goldin, Claudia and Lawrence Katz (2011). "Mass Secondary Schooling and the State: The Role of State Compulsion in the High School Movement" in Understanding Long-Run Economic Growth: Geography, Institutions, and the Knowledge Economy, Dora L. Costa and Naomi R. Lamoreaux, eds., University of Chicago Press.

Goldin, Claudia and Robert Margo (1992). "The Great Compression: The Wage Structure in the United States at Mid-century." Quarterly Journal of Economics, 107:1-34.

Landes, William and Lewis Solmon (1972). "Compulsory attendance Legislation: An Economic Analysis of Law and Social Change in the Nineteen Century." Journal of Economic History, 32:54-91.

Lindert, Peter (2000). "Three Centuries of Inequality in Britain and America," in Handbook of Income Distribution, eds. Anthony B. Atkinson and Francois Bourguignon. Amsterdam/New York: Elsevier/North Holland. 
Lleras-Muney, Adrianna (2002). "Were Compulsory Attendance and Child Labor Laws Effective? An Analysis from 1915-1939.” Journal of Law and Economics, 45: 401-435.

Margo, Robert and T. Aldrich Finnegan (1996). "Compulsory attendance Legislation and School Attendance in Turn of the Century America: A 'Natural Experiment' Approach." Economics Letters, 53: 103-110.

Mayman, Edward J. (1933). "The Evolution of the Continuation School in New York City." The School Review 41: 193-205.

McAfee, Ward M. (1998). Religion, Race, and Reconstruction: The Public School in the Politics of the 1870s. Albany: State University of New York Press.

Moehling, Carolyn (1999). "State Child Labor Laws and the Decline of Child Labor." Explorations in Economic History, 36:72-106.

Moreira, Marcelo J. (2003). "A Conditional Likelihood Ratio Test for Structural Models," Econometrica, 71(4):1027-1048.

Puerta, Juan Manuel (2011) Essays on the Economic History of the Family, PhD Dissertation, Universitat Pompeu Fabra.

Ralph, John H., and Richard Rubinson (1980). "Immigration and the Expansion of Schooling in the United States, 1890-1970.” American Sociological Review (1980): 943-954.

Ruggles, Steven, Katie Genadek, Ronald Goeken, Josiah Grover, and Matthew Sobek. Integrated Public Use Microdata Series: Version 6.0 [Machine-readable database]. Minneapolis: University of Minnesota, 2015.

Staiger, Douglas and James H. Stock (1997). "Instrumental Variables Regression with Weak Instruments," Econometrica 65: 557-586. 
Stephens Jr., Melvin and Dou-Yan Yang (2014). "Compulsory Education and the Benefits of Schooling." American Economic Review, June 2014, 104(6):1777-1792.

Tyack, David, James Thomas, and Aaron Benavot (1987). Law and the Shaping of Public Education, 1785-1954. The University of Wisconsin Press.

U.S. Office [Bureau] of Education (various years). Report of the Commissioner of Education for the Year Ended_.. Washington, D.C.: Government Printing Office. 
Figure 1: Passage of State Laws Affecting School Attendance, 1880-1930

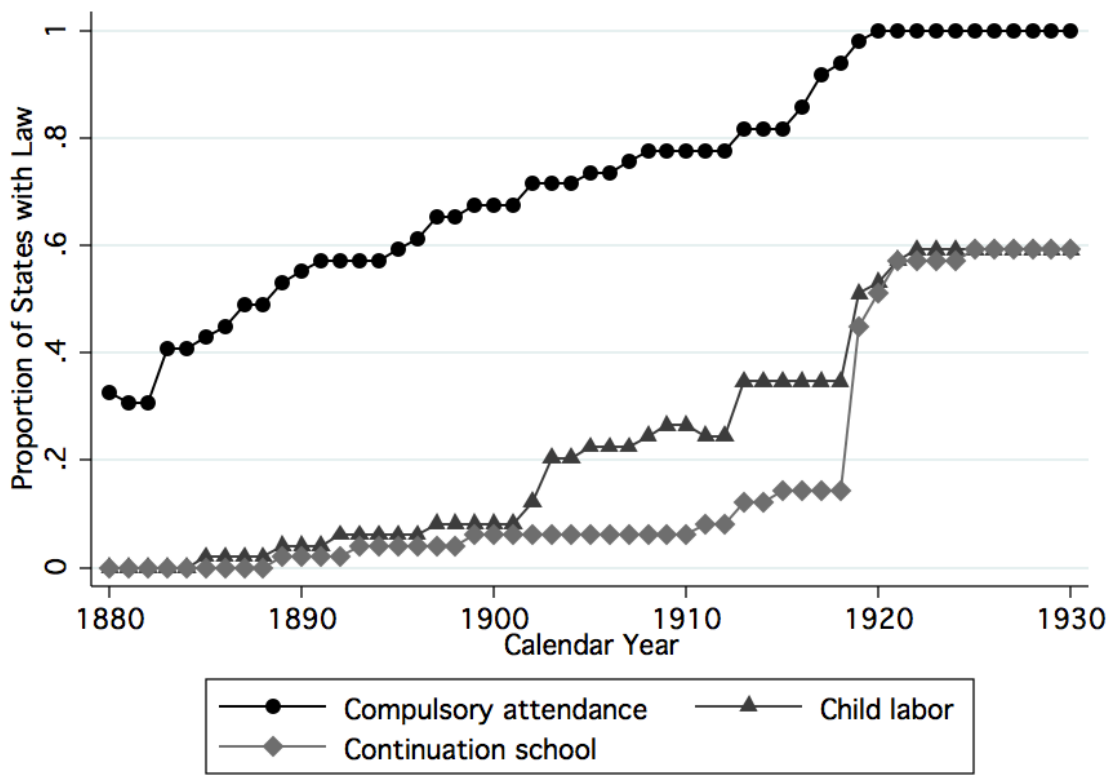

Notes: Figure shows proportion of states with a compulsory attendance law, child labor law exempting working children from compulsory attendance requirements, and continuation schooling law for working children in each calendar year. This figure shows the existence of a law on the books, not whether the law bound children in practice. See the dataset attached in the online Data Appendix for sources.

Figure 2: Completed Years of Schooling by Year of Birth, Native-Born White Men

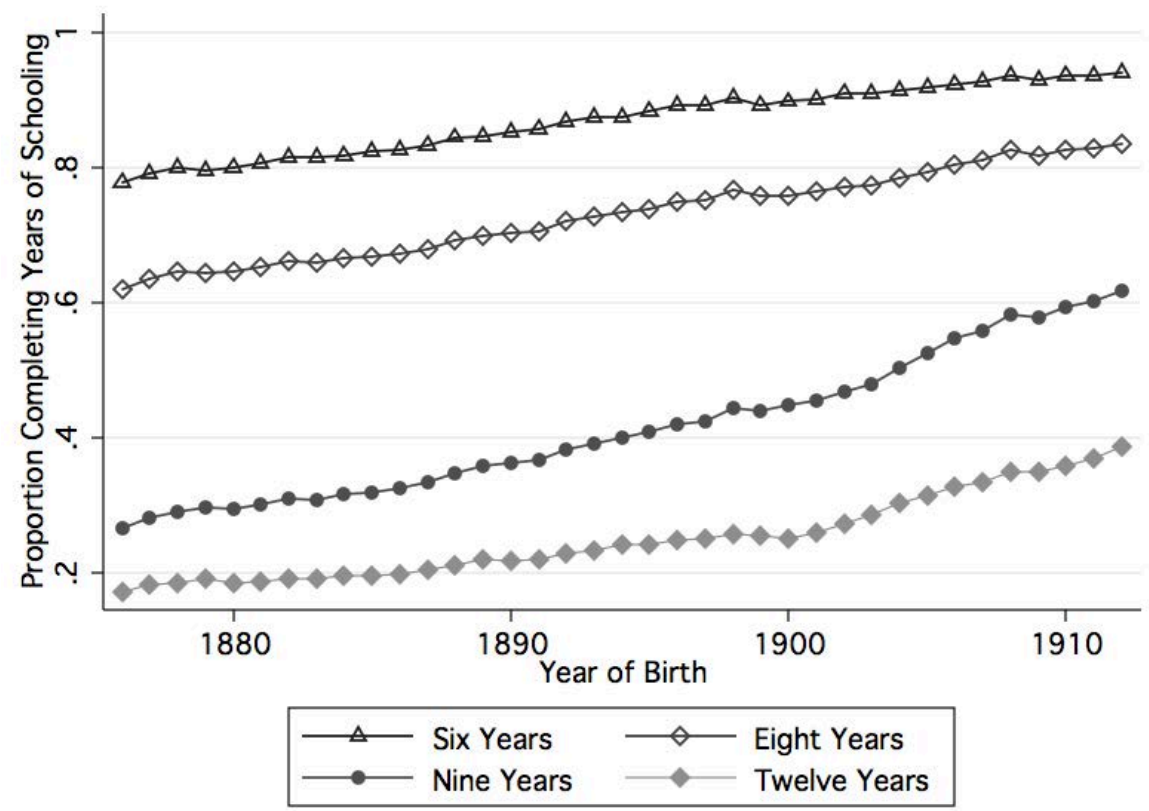

Notes: Figure shows the population-weighted proportion of native-born white males reporting at least six, eight, nine, or twelve years of schooling, by year of birth. Data are from the complete count of the 1940 census. 
Figure 3: Required Years of Education by Year of Birth

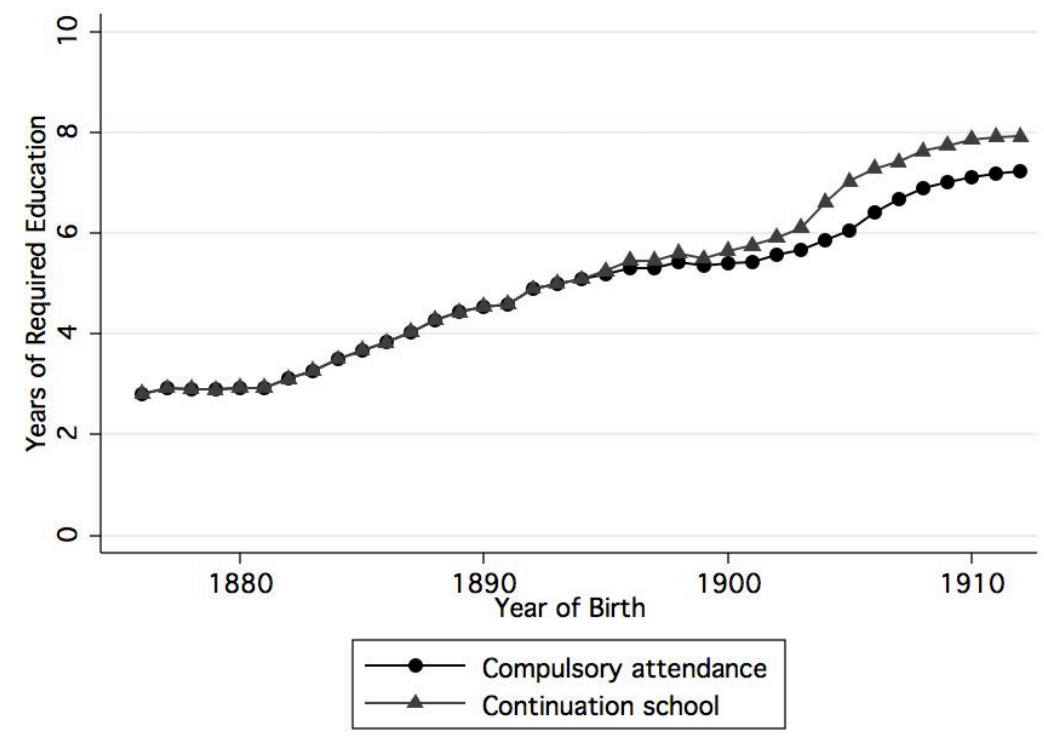

Notes: Figure shows the population-weighted average years of required education by year of birth, according to state compulsory attendance laws (accounting for years of schooling exemptions, in which children who had completed sufficient schooling could drop out, and child labor exemptions, in which employed children with sufficient schooling could drop out) and state continuation schooling laws (accounting for years of schooling exemptions). Years of required education are calculated for each birth cohort as described in the online Data Appendix. Weights are calculated from the size of year-of-birth cohorts in the 1940 census.

\section{Figure 4: Effect of the Laws on Completed Years of Schooling, Native-Born White Men}

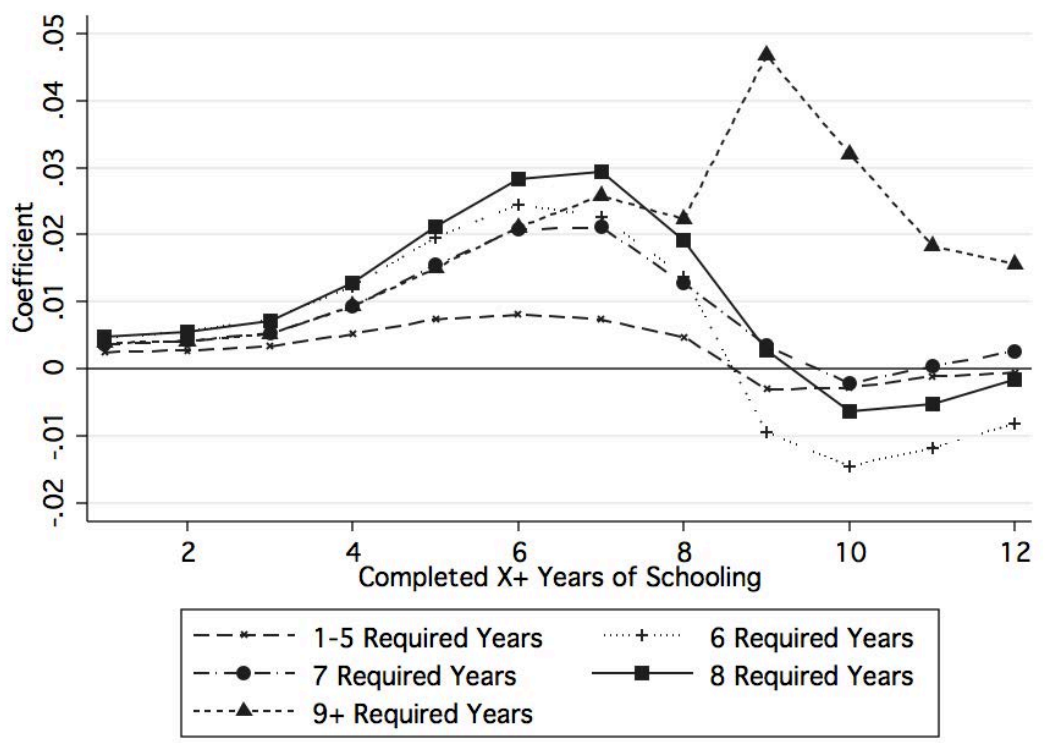

Notes: Figure shows the coefficients from regressing completed years of schooling on laws using individuals who were born between 1885 and 1912, inclusive. The outcome in each regression is a binary indicator for having completed at least as many years as shown on the axes. Results are shown for the all white men sample that has $18,887,147$ observations. Each regression includes state of birth and region by year of birth fixed effects. See Appendix Table 1 for full results. 
Figure 5: Quantile Instrumental Variable Regression Estimates of Returns to Schooling, NativeBorn White Men

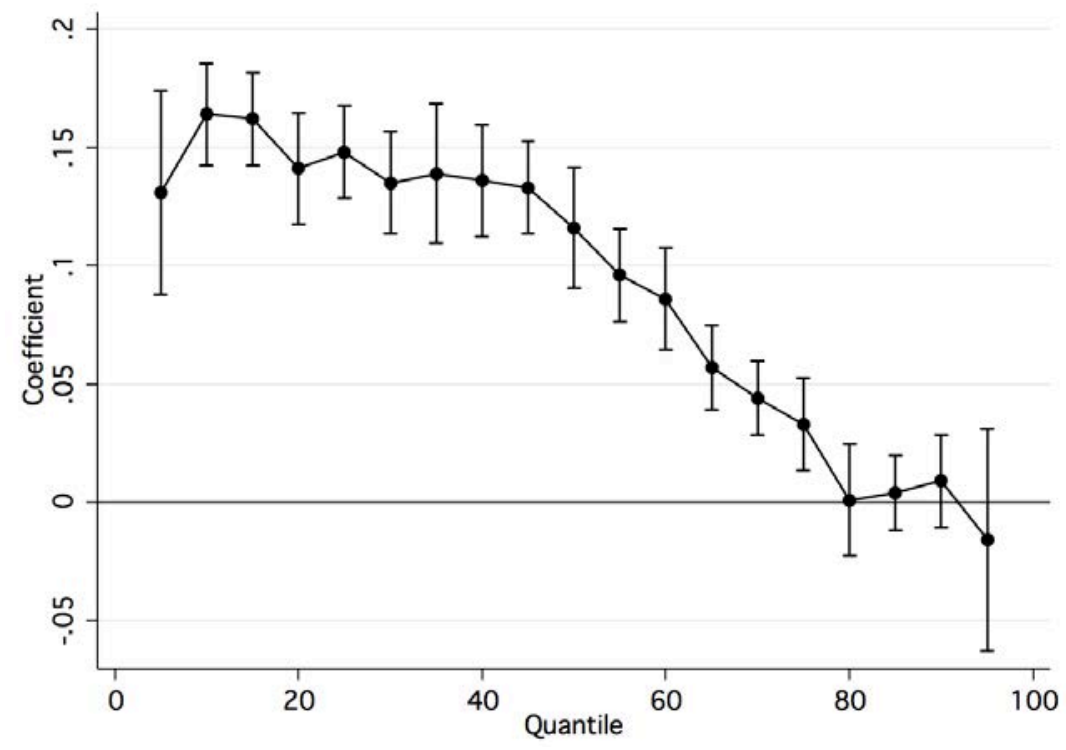

Notes: Each coefficient is from a separate regression, and error bars show 95\% confidence intervals. Results are shown for a random $25 \%$ sample of the working men sample: all white men who reported positive earnings and positive weeks worked in 1939. This sample contains 3,306,178 observations. Each regression includes state of birth and region by year of birth fixed effects. See Appendix Table 3, Panel A for full results. 
Figure 6: Quantile Instrumental Variable Regression Estimates of Returns to Schooling, NativeBorn Parents and Comparison Samples

Panel A: Sample Line Individuals

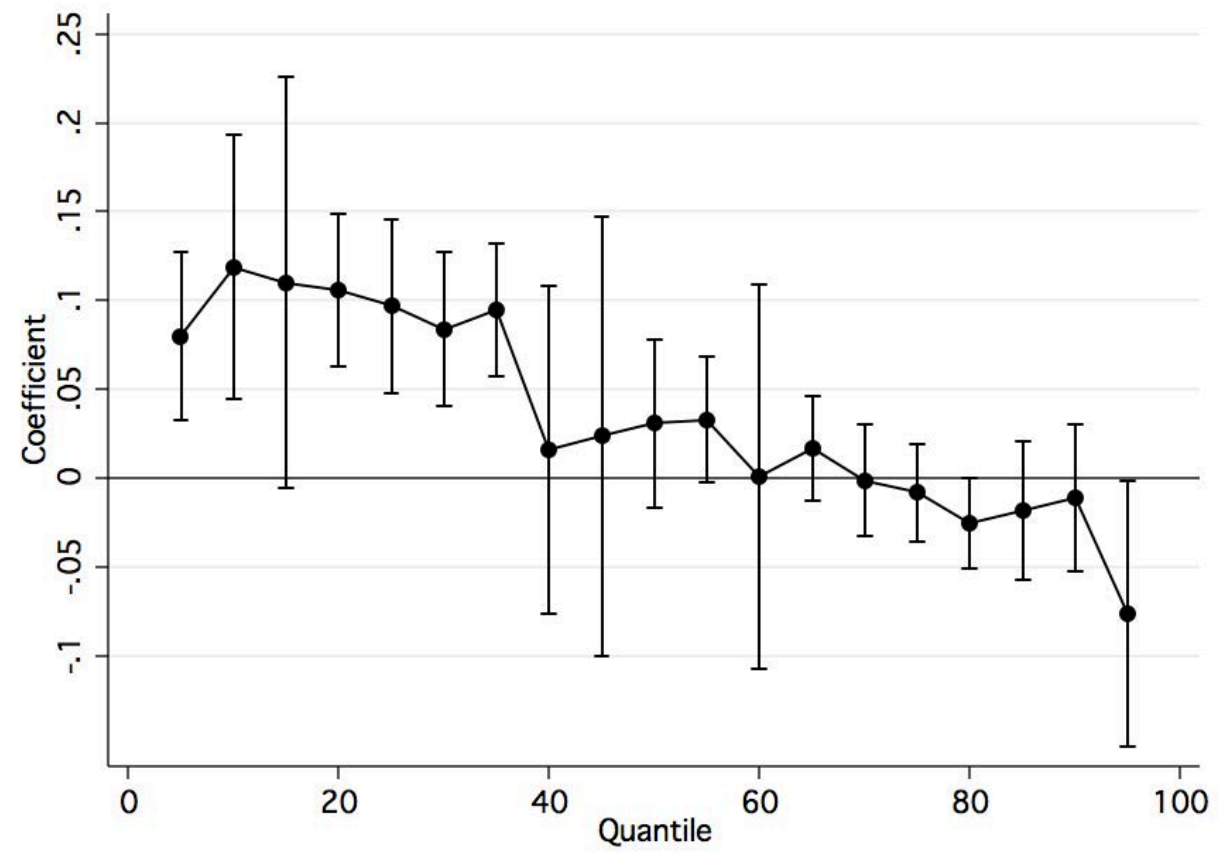

Panel B: Native Parents Only Sample Line Individuals

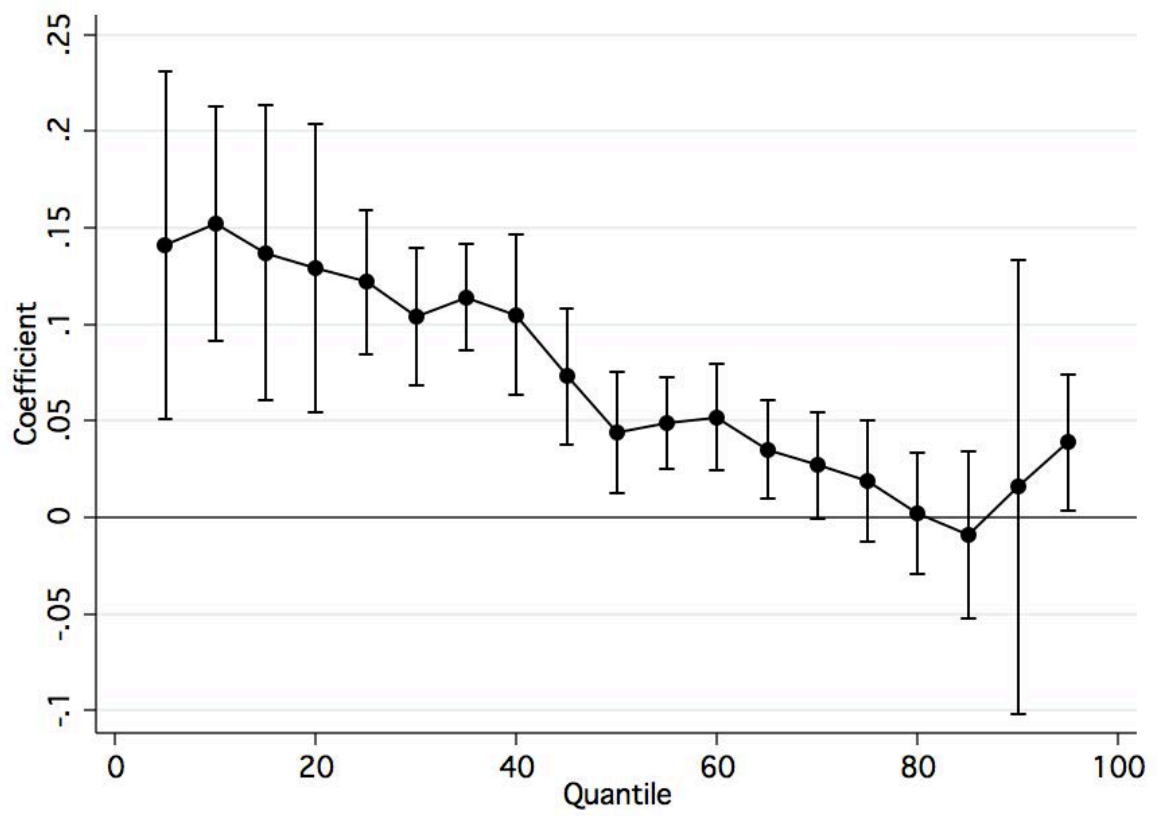

Notes: Each coefficient is from a separate regression, and error bars show 95\% confidence intervals. Results are shown using the working men sample: all white men who reported positive earnings and positive weeks worked in 1939. Panel A uses the 638,239 observations from the working men sample who are sample line individuals. Panel B uses the 471,363 observations from the working men sample who are sample line individuals and have both parents that are native born. Standard errors are clustered by state and year. Each regression includes state of birth and region by year of birth fixed effects. See Appendix Table 5, Panels B and C for full results. 
Table 1: Summary statistics

\begin{tabular}{|c|c|c|c|}
\hline Variables & All Men & $\begin{array}{l}\text { Sample: } \\
\text { Working } \\
\text { Men }\end{array}$ & $\begin{array}{c}\text { Restricted } \\
\text { Working } \\
\text { Men }\end{array}$ \\
\hline Age & 38.9 & 38.2 & 38.2 \\
\hline Years of Schooling & 9.22 & 9.37 & 9.88 \\
\hline Log Weekly Wage & & 3.18 & 3.34 \\
\hline \multicolumn{4}{|l|}{ Required Schooling: } \\
\hline Percent Zero Years & 13.5 & 11.3 & 10.2 \\
\hline Percent One to Five Years & 9.2 & 8.8 & 8.4 \\
\hline Percent Six Years & 19.1 & 19.0 & 19.3 \\
\hline Percent Seven Years & 16.9 & 16.9 & 17.6 \\
\hline Percent Eight Years & 33.4 & 35.2 & 35.2 \\
\hline Percent Nine or More Years & 7.9 & 8.8 & 9.3 \\
\hline $\mathrm{N}$ & $18,887,147$ & $13,224,713$ & $8,383,586$ \\
\hline
\end{tabular}


Table 2: Effect of the Laws on Years of Schooling for Native-Born White Men

\begin{tabular}{|c|c|c|c|c|c|c|}
\hline \multirow{2}{*}{$\begin{array}{l}\text { Sample: } \\
\text { Laws }\end{array}$} & \multicolumn{2}{|c|}{ All Men } & \multicolumn{2}{|c|}{ Working Men } & \multicolumn{2}{|c|}{ Restricted Working Men } \\
\hline & $(1)$ & $(2)$ & (3) & (4) & $(5)$ & $(6)$ \\
\hline \multicolumn{7}{|l|}{ Continuous Laws (Years) } \\
\hline Required Schooling & $\begin{array}{l}0.019 * * * \\
(0.003)\end{array}$ & & $\begin{array}{c}0.022 * * * \\
(0.004)\end{array}$ & & $\begin{array}{c}0.022 * * * \\
(0.004)\end{array}$ & \\
\hline \multicolumn{7}{|l|}{ Categorical Laws } \\
\hline $\begin{array}{l}\text { Required Schooling: } \\
\text { One to Five Years }\end{array}$ & & $\begin{array}{l}0.039 * * \\
(0.017)\end{array}$ & & $\begin{array}{l}0.033 * \\
(0.017)\end{array}$ & & $\begin{array}{c}0.017 \\
(0.019)\end{array}$ \\
\hline Six Years & & $\begin{array}{c}0.045 * * \\
(0.021)\end{array}$ & & $\begin{array}{c}0.048 * * \\
(0.021)\end{array}$ & & $\begin{array}{c}0.034 \\
(0.022)\end{array}$ \\
\hline Seven Years & & $\begin{array}{l}0.094 * * * \\
(0.022)\end{array}$ & & $\begin{array}{l}0.104 * * * \\
(0.023)\end{array}$ & & $\begin{array}{c}0.105 * * * \\
(0.024)\end{array}$ \\
\hline Eight Years & & $\begin{array}{c}0.123 * * * \\
(0.024)\end{array}$ & & $\begin{array}{c}0.138 * * * \\
(0.025)\end{array}$ & & $\begin{array}{c}0.135 * * * \\
(0.026)\end{array}$ \\
\hline Nine or More Years & & $\begin{array}{c}0.246^{* *} \\
(0.029)\end{array}$ & & $\begin{array}{l}0.263 * * * \\
(0.029)\end{array}$ & & $\begin{array}{l}0.213 * * * \\
(0.030)\end{array}$ \\
\hline $\mathrm{N}$ & $18,887,147$ & $18,887,147$ & $13,224,713$ & $13,224,713$ & $8,383,586$ & $8,383,586$ \\
\hline
\end{tabular}

Notes: Each column in the table presents the results of a separate regression using individuals who were born between 1885 and 1912 , inclusive. Results are shown for three samples: all native-born white men (Columns 1-2), all white men who reported positive earnings and positive weeks worked in 1939 (Columns 3-4), and all white men who reported positive earnings and worked at least 40 weeks in 1939, works but is not self-employed, and did not live on a farm (Columns 5-6). The independent variables shown in the table are a continuous measure of required years of schooling that includes continuation schooling requirements (Columns 1, 3, and 5) and indicators for required years of schooling that includes continuation schooling requirements (Columns 2, 4, and 6). Each regression includes state of birth and region by year of birth fixed effects. Standard errors are clustered by state and year. Significance is represented by $* * *$ at the .01 level, $* *$ at the .05 level, and $*$ at the .10 level. 
Table 3: Literature Review of Effects of Laws on Educational Outcomes

\begin{tabular}{|c|c|c|c|c|c|}
\hline Paper & Identification & Data & Sample & Time period & Effects of laws \\
\hline $\begin{array}{l}\text { Landes and Solmon } \\
\text { (1972) }\end{array}$ & DD laws-time & $\begin{array}{l}\text { Administrative } \\
\text { attendance, enrollment }\end{array}$ & $\begin{array}{l}\text { State-year averages } \\
\text { from administrative } \\
\text { data }\end{array}$ & $1870-1880,1880-1890$ & No \\
\hline $\begin{array}{l}\text { Margo and Finegan } \\
\text { (1996) }\end{array}$ & $\begin{array}{l}\text { DD laws-older and } \\
\text { younger } 14 \text { year olds } \\
\text { in } 1900\end{array}$ & $\begin{array}{l}1900 \text { Census sample } \\
\text { In school }\end{array}$ & 1/760 Preston sample & 1900 & $\begin{array}{l}\text { Yes for states with } \\
\text { attendance }+ \text { labor }\end{array}$ \\
\hline Lleras Muney (2002) & $\begin{array}{l}\text { DD Time series } \\
\text { State FE, Year FE, } \\
\text { Region x year FE }\end{array}$ & $\begin{array}{l}1960 \text { Census sample } \\
\text { Years of schooling }\end{array}$ & 1/100 sample & $1915-1939$ & Yes, all laws \\
\hline $\begin{array}{l}\text { Goldin and Katz } \\
\text { (2011) }\end{array}$ & $\begin{array}{l}\text { DD Time series } \\
\text { State FE, Year FE, } \\
\text { Region x TT }\end{array}$ & $\begin{array}{l}1960 \text { Census sample } \\
\text { Years of schooling } \\
1910,1920 \\
\text { working, in school } \\
\text { Administrative }\end{array}$ & 1/100 samples & $\begin{array}{l}1910-1939 \\
(1896-1925 \\
\text { birth cohorts })\end{array}$ & $\begin{array}{l}\text { Yes, primarily } \\
\text { continuation } \\
\text { schooling, they note } \\
\text { effects modest }\end{array}$ \\
\hline Puerta (2011) & $\begin{array}{l}\text { DD laws-time in } \\
\text { border } \\
\text { townships/counties }\end{array}$ & $\begin{array}{l}\text { 1850-1910 Census } \\
\text { samples } \\
\text { In school }\end{array}$ & $1 / 100-1 / 20$ samples & $1850-1910$ & $\begin{array}{l}\text { Yes, bigger for early } \\
(1850-1870) \text { than late } \\
(1880-1910)\end{array}$ \\
\hline $\begin{array}{l}\text { Lleras-Muney and } \\
\text { Shertzer (2015) }\end{array}$ & $\begin{array}{l}\text { DD Time series } \\
\text { State FE, Year FE, } \\
\text { State TT }\end{array}$ & $\begin{array}{l}1910,1920, \text { and } 1930 \\
\text { Census samples, } 1940 \\
\text { Census, WWII records }\end{array}$ & 1/100 samples & $\begin{array}{l}1910-1930 \\
(1904-1924 \\
\text { birth cohorts })\end{array}$ & $\begin{array}{l}\text { Yes, larger effects on } \\
\text { enrollment for children } \\
\text { born abroad than } \\
\text { native-born children }\end{array}$ \\
\hline $\begin{array}{l}\text { Clay, Lingwall, } \\
\text { Stephens (2016) }\end{array}$ & $\begin{array}{l}\text { DD laws-time } \\
\text { State FE, Year FE, } \\
\text { Region x Year FE }\end{array}$ & $\begin{array}{l}\text { Complete } 1940 \text { Census } \\
\text { Years of schooling }\end{array}$ & Full census, white men & $\begin{array}{l}1899-1926 \\
(1885-1912 \\
\text { birth cohorts })\end{array}$ & $\begin{array}{l}\text { Yes, effects modest } \\
\text { and nonlinear. }\end{array}$ \\
\hline
\end{tabular}


Table 4: Returns to Schooling for Native-Born White Men

\begin{tabular}{|c|c|c|c|c|c|c|}
\hline \multirow{3}{*}{$\begin{array}{l}\text { Sample: } \\
\text { Specification: } \\
\text { Laws }\end{array}$} & \multicolumn{3}{|c|}{ Working Men } & \multicolumn{3}{|c|}{ Restricted Working Men } \\
\hline & OLS & $\begin{array}{c}2 \text { 2SLS } \\
\text { Continuous }\end{array}$ & $\begin{array}{c}\text { 2SLS } \\
\text { Categorical }\end{array}$ & OLS & $\begin{array}{c}\text { 2SLS } \\
\text { Continuous }\end{array}$ & $\begin{array}{c}\text { 2SLS } \\
\text { Categorical }\end{array}$ \\
\hline & $(1)$ & (2) & (3) & (4) & $(5)$ & (6) \\
\hline Years of Schooling & $\begin{array}{c}0.082 * * * \\
(0.001)\end{array}$ & $\begin{array}{c}0.159 * * * \\
(0.026)\end{array}$ & $\begin{array}{c}0.079 * * * \\
(0.015)\end{array}$ & $\begin{array}{c}0.068 * * * \\
(0.001)\end{array}$ & $\begin{array}{c}0.120 * * * \\
(0.022)\end{array}$ & $\begin{array}{c}0.064 * * * \\
(0.016)\end{array}$ \\
\hline First Stage F-Stat & & 37.7 & 29.0 & & 34.0 & 20.1 \\
\hline $\mathrm{N}$ & $13,224,713$ & $13,224,713$ & $13,224,713$ & $8,383,586$ & $8,383,586$ & $8,383,586$ \\
\hline
\end{tabular}

Notes: Each column in the table presents the results of a separate regression of log weekly wages on years of schooling using individuals who were born between 1885 and 1912, inclusive. Results are shown for two samples: all white men who reported positive earnings and positive weeks worked in 1939 (Columns 1-3), and all white men who reported positive earnings and worked at least 40 weeks in 1939, works but is not self-employed, and did not live on a farm (Columns 4 6). We present OLS estimates of the returns to schooling (Columns 1 and 4), IV estimates of the returns to schooling using a single continuous measure of required years of schooling that includes continuation schooling requirements (Columns 2 and 5) and IV estimates of the returns to schooling using indicators for required years of schooling that includes continuation schooling requirements (Columns 3 and 6). The corresponding first stage estimates are found in Table 3. Each regression includes state of birth and region by year of birth fixed effects. Standard errors are clustered by state and year. Significance is represented by $* * *$ at the .01 level, ** at the .05 level, and * at the .10 level. 
Table 5: Literature Review on Returns to Schooling

\begin{tabular}{|c|c|c|c|c|c|}
\hline Paper & Identification & Data & Laws & Time period & Returns \\
\hline $\begin{array}{l}\text { Angrist and Krueger } \\
\text { (1991) }\end{array}$ & IV time series & $\begin{array}{l}\text { 1970-1980 Censuses } \\
\text { (1-5\% samples) }\end{array}$ & $\begin{array}{l}\text { Quarter of birth } \\
\text { attendance }\end{array}$ & $\begin{array}{l}1920-1949 \text { birth } \\
\text { cohorts }\end{array}$ & $\begin{array}{l}\text { Yes, IV larger than } \\
\text { OLS }\end{array}$ \\
\hline $\begin{array}{l}\text { Staiger and Stock } \\
\text { (1997) }\end{array}$ & IV time series & $\begin{array}{l}1980 \text { Census } \\
(5 \% \text { sample })\end{array}$ & $\begin{array}{l}\text { Quarter of birth } \\
\text { attendance }\end{array}$ & $\begin{array}{l}\text { 1930-1949 birth } \\
\text { cohorts }\end{array}$ & $\begin{array}{l}\text { Yes, IV larger than } \\
\text { OLS }\end{array}$ \\
\hline $\begin{array}{l}\text { Goldin and Katz } \\
(2000)\end{array}$ & Cross sectional & $\begin{array}{l}1915 \text { Iowa Census } \\
\text { (2.5\% sample) }\end{array}$ & & $\begin{array}{l}1850-1897 \text { birth } \\
\text { cohorts }\end{array}$ & $\begin{array}{l}\text { Yes, smaller for } \\
\text { primary school, larger } \\
\text { for high school/college }\end{array}$ \\
\hline $\begin{array}{l}\text { Oreopoulos and } \\
\text { Salvanes (2011) }\end{array}$ & IV time series & $\begin{array}{l}\text { 1950-2000 Censuses } \\
\text { (0.3-1\% samples), } \\
\text { ACS 2001-2007 }\end{array}$ & Attendance & $\begin{array}{l}1899-1982 \text { birth } \\
\text { cohorts }\end{array}$ & $\begin{array}{l}\text { Yes, IV larger than } \\
\text { OLS }\end{array}$ \\
\hline $\begin{array}{l}\text { Stephens and Yang } \\
\text { (2014) }\end{array}$ & $\begin{array}{l}\text { IV time series } \\
\text { State FE, Year FE, } \\
\text { Region x Year FE }\end{array}$ & $\begin{array}{l}\text { 1960-1980 Censuses } \\
\text { (1-5\% samples) }\end{array}$ & Attendance & $\begin{array}{l}\text { 1905-1954 birth } \\
\text { cohorts }\end{array}$ & $\begin{array}{l}\text { No, if controls for } \\
\text { Region x Year FE are } \\
\text { included }\end{array}$ \\
\hline
\end{tabular}


Table 6: Effect of the Laws on Years of Schooling for Native-Born White Men with Native-Born and Foreign-Born Parents

\begin{tabular}{|c|c|c|c|c|c|c|}
\hline Sample: & Full Sample & \multicolumn{5}{|c|}{ Sample Line } \\
\hline Sample: & All & \multicolumn{3}{|c|}{ All } & $\begin{array}{c}\text { Parents } \\
\text { Native-born }\end{array}$ & $\begin{array}{r}1+\text { Parent(s) } \\
\text { Foreign-born }\end{array}$ \\
\hline Laws & $(1)$ & $(2)$ & (3) & (4) & $(5)$ & (6) \\
\hline Required Schooling & $\begin{array}{c}0.019 * * * \\
(0.003)\end{array}$ & $\begin{array}{c}0.019 * * * \\
(0.005)\end{array}$ & $\begin{array}{c}0.021 * * * \\
(0.005)\end{array}$ & $\begin{array}{c}0.021 * * * \\
(0.006)\end{array}$ & $\begin{array}{c}0.026 * * * \\
(0.006)\end{array}$ & $\begin{array}{l}0.017 * \\
(0.010)\end{array}$ \\
\hline Foreign-born Parent & & & $\begin{array}{c}-0.600 * * * \\
(0.019)\end{array}$ & $\begin{array}{c}-0.618 * * * \\
(0.109)\end{array}$ & & \\
\hline Laws*Foreign-born Parent & & & & $\begin{array}{c}0.003 \\
(0.015)\end{array}$ & & \\
\hline $\mathrm{N}$ & $18,887,147$ & 905,796 & 905,796 & 905,796 & 674,139 & 231,657 \\
\hline
\end{tabular}

Notes: Each column in the table presents the results of a separate regression using individuals who were born between 1885 and 1912 , inclusive. Results are shown for four samples: all white men (Column 1), all white men who are in the sample line individuals (Columns 2-4), all white men in the sample line individuals with both parents born in the United States, (Column 5), and all white men in the sample line individuals with one or both parents born outside of the United States. (Column 6). The independent variables shown in the table are a continuous measure of required years of schooling that includes continuation schooling requirements, an indicator for having at least one parent born outside of the United States (Columns 3-4) and an interaction between the continuous measure of required schooling (including continuation schooling) and an indicators for having at least one parent born outside of the United States (Column 4). Each regression includes state of birth and region by year of birth fixed effects. Standard errors are clustered by state and year. Significance is represented by $* * *$ at the .01 level, ** at the .05 level, and * at the .10 level. 
Table 7: Returns to Schooling for Native-Born White Men with Native-Born Parents

\begin{tabular}{|c|c|c|c|c|c|c|}
\hline \multirow{4}{*}{$\begin{array}{l}\text { Sample: } \\
\text { Specification: } \\
\text { Laws }\end{array}$} & \multicolumn{6}{|c|}{ Panel A: All Sample Line - Full Sample Specification } \\
\hline & \multicolumn{3}{|c|}{ Working Men } & \multicolumn{3}{|c|}{ Restricted Working Men } \\
\hline & OLS & $\begin{array}{c}\text { 2SLS } \\
\text { Continuous }\end{array}$ & $\begin{array}{c}\text { 2SLS } \\
\text { Categorical }\end{array}$ & OLS & $\begin{array}{c}2 \text { SLS } \\
\text { Continuous }\end{array}$ & $\begin{array}{c}\text { 2SLS } \\
\text { Categorical }\end{array}$ \\
\hline & (1) & $(2)$ & (3) & (4) & $(5)$ & $(6)$ \\
\hline \multirow{3}{*}{$\begin{array}{l}\text { Years of Schooling } \\
\text { First Stage F-Stat } \\
\text { N }\end{array}$} & $\begin{array}{c}0.081 * * * \\
(0.001)\end{array}$ & $\begin{array}{c}0.123 * * * \\
(0.050)\end{array}$ & $\begin{array}{c}0.030 \\
(0.029)\end{array}$ & $\begin{array}{c}0.068 * * * \\
(0.001)\end{array}$ & $\begin{array}{c}0.100 * * * \\
(0.041)\end{array}$ & $\begin{array}{c}0.060 * * \\
(0.025)\end{array}$ \\
\hline & & 14.8 & 11.2 & & 13.1 & 8.5 \\
\hline & 638,239 & 638,239 & 638,239 & 406,225 & 406,225 & 406,225 \\
\hline \multirow{3}{*}{$\begin{array}{l}\text { Sample: } \\
\text { Specification: }\end{array}$} & \multicolumn{6}{|c|}{ Panel B: All Sample Line - Including Foreign-born Indicator } \\
\hline & \multicolumn{3}{|c|}{ Working Men } & \multicolumn{3}{|c|}{ Restricted Working Men } \\
\hline & OLS & $\begin{array}{c}2 \text { SLS } \\
\text { Continuous }\end{array}$ & $\begin{array}{c}\text { 2SLS } \\
\text { Categorical }\end{array}$ & OLS & $\begin{array}{c}2 \text { SLS } \\
\text { Continuous }\end{array}$ & $\begin{array}{c}2 \text { 2SLS } \\
\text { Categorical }\end{array}$ \\
\hline Laws & $(1)$ & $(2)$ & (3) & (4) & $(5)$ & $(6)$ \\
\hline Years of Schooling & $\begin{array}{c}0.082 * * * \\
(0.001)\end{array}$ & $\begin{array}{c}0.112 * * * \\
(0.046)\end{array}$ & $\begin{array}{c}0.021 \\
(0.026)\end{array}$ & $\begin{array}{c}0.068 * * * \\
(0.001)\end{array}$ & $\begin{array}{c}0.093 * * * \\
(0.038)\end{array}$ & $\begin{array}{c}0.053 * * \\
(0.023)\end{array}$ \\
\hline First Stage F-Stat & & 16.7 & 14.1 & & 15.0 & 11.1 \\
\hline $\mathrm{N}$ & 638,239 & 638,239 & 638,239 & 406,225 & 406,225 & 406,225 \\
\hline \multirow{3}{*}{$\begin{array}{l}\text { Sample: } \\
\text { Specification: }\end{array}$} & \multicolumn{6}{|c|}{ Panel C: Native-born Parents Sample Line } \\
\hline & \multicolumn{3}{|c|}{ Working Men } & \multicolumn{3}{|c|}{ Restricted Working Men } \\
\hline & OLS & $\begin{array}{c}\text { 2SLS } \\
\text { Continuous }\end{array}$ & $\begin{array}{c}\text { 2SLS } \\
\text { Categorical }\end{array}$ & OLS & $\begin{array}{c}\text { 2SLS } \\
\text { Continuous }\end{array}$ & $\begin{array}{c}\text { 2SLS } \\
\text { Categorical }\end{array}$ \\
\hline Laws & $(1)$ & (2) & (3) & (4) & $(5)$ & (6) \\
\hline Years of Schooling & $\begin{array}{c}0.087 * * * \\
(0.001)\end{array}$ & $\begin{array}{c}0.134 * * * \\
(0.045)\end{array}$ & $\begin{array}{c}0.077 * * * \\
(0.025)\end{array}$ & $\begin{array}{c}0.072 * * * \\
(0.001)\end{array}$ & $\begin{array}{c}0.085^{* * *} * \\
(0.033)\end{array}$ & $\begin{array}{c}0.074 * * * \\
(0.022)\end{array}$ \\
\hline First Stage F-Stat & & 21.0 & 15.0 & & 23.4 & 13.3 \\
\hline $\mathrm{N}$ & 471,363 & 471,363 & 471,363 & 294,728 & 294,728 & 294,728 \\
\hline
\end{tabular}

Notes: Each estimate in the table presents the results of a separate regression using individuals who were born between 1885 and 1912, inclusive. Results are shown for two samples: all white men who reported positive earnings and positive weeks worked in 1939 (Columns 1-3), and all white men who reported positive earnings and worked at least 40 weeks in 1939, works but is not self-employed, and does not live on a farm (Columns 4-6). We present OLS estimates of the returns to schooling (Columns 1 and 4), IV estimates of the returns to schooling using a single continuous measure of required years of schooling that includes continuation schooling requirements (Columns 2 and 5) and IV estimates of the returns to schooling using indicators for required years of schooling that includes continuation schooling requirements (Columns 3 and 6). The corresponding first stage estimates are found in Table 3. Each regression includes state of birth and region by year of birth fixed effects. Standard errors are clustered by state and year. Significance is represented by *** at the .01 level, ** at the .05 level, and * at the .10 level. 
Table 8: Effect of the Laws on Years of Schooling for Native-Born White Men, Excluding the South

\begin{tabular}{|c|c|c|c|c|c|c|}
\hline \multirow{2}{*}{$\begin{array}{l}\text { Sample: } \\
\text { Laws }\end{array}$} & \multicolumn{2}{|c|}{ All Men } & \multicolumn{2}{|c|}{ Working Men } & \multicolumn{2}{|c|}{ Restricted Working Men } \\
\hline & (1) & $(2)$ & (3) & (4) & $(5)$ & (6) \\
\hline \multicolumn{7}{|l|}{ Continuous Laws (Years) } \\
\hline Required Schooling & $\begin{array}{c}0.016^{* * * *} \\
(0.004)\end{array}$ & & $\begin{array}{c}0.020 * * * \\
(0.004)\end{array}$ & & $\begin{array}{c}0.018 * * * \\
(0.004)\end{array}$ & \\
\hline \multicolumn{7}{|l|}{ Categorical Laws } \\
\hline One to Five Years & & $\begin{array}{c}0.012 \\
(0.028)\end{array}$ & & $\begin{array}{l}-0.018 \\
(0.027)\end{array}$ & & $\begin{array}{l}-0.047 * \\
(0.028)\end{array}$ \\
\hline Six Years & & $\begin{array}{c}0.009 \\
(0.027)\end{array}$ & & $\begin{array}{l}-0.007 \\
(0.024)\end{array}$ & & $\begin{array}{l}-0.032 \\
(0.025)\end{array}$ \\
\hline Seven Years & & $\begin{array}{c}0.058^{* *} \\
(0.028)\end{array}$ & & $\begin{array}{l}0.052^{* *} \\
(0.026)\end{array}$ & & $\begin{array}{c}0.039 \\
(0.027)\end{array}$ \\
\hline Eight Years & & $\begin{array}{c}0.083^{* *} \\
(0.030)\end{array}$ & & $\begin{array}{c}0.081^{* *} \\
(0.028)\end{array}$ & & $\begin{array}{c}0.063 * * \\
(0.030)\end{array}$ \\
\hline Nine or More Years & & $\begin{array}{c}0.204 * * * \\
(0.035)\end{array}$ & & $\begin{array}{c}0.203 * * * \\
(0.033)\end{array}$ & & $\begin{array}{c}0.139 * * * \\
(0.034)\end{array}$ \\
\hline $\mathrm{N}$ & $14,781,297$ & $14,781,297$ & $10,606,026$ & $10,606,026$ & $6,871,341$ & $6,871,341$ \\
\hline
\end{tabular}

Notes: Each column in the table presents the results of a separate regression using individuals who were born between 1885 and 1912, inclusive. Results are shown for three samples: all white men (Columns 1-2), all white men who reported positive earnings and positive weeks worked in 1939 (Columns 3-4), and all white men who reported positive earnings and worked at least 40 weeks in 1939, works but is not self-employed, and does not live on a farm (Columns 5-6). The independent variables shown in the table are a continuous measure of required years of schooling that includes continuation schooling requirements (Columns 1, 3, and 5) and indicators for required years of schooling that includes continuation schooling requirements (Columns 2, 4, and 6). Each regression includes state of birth and region by year of birth fixed effects. Standard errors are clustered by state and year. Significance is represented by $* * *$ at the .01 level, $* *$ at the .05 level, and * at the .10 level. 
Table 9: Returns to Schooling for Native-born White Men, Excluding the South

\begin{tabular}{|c|c|c|c|c|c|c|}
\hline \multirow{3}{*}{$\begin{array}{l}\text { Sample: } \\
\text { Specification: } \\
\text { Laws }\end{array}$} & \multicolumn{3}{|c|}{ Working Men } & \multicolumn{3}{|c|}{ Restricted Working Men } \\
\hline & OLS & $\begin{array}{c}\text { 2SLS } \\
\text { Continuous }\end{array}$ & $\begin{array}{c}\text { 2SLS } \\
\text { Categorical }\end{array}$ & OLS & $\begin{array}{c}2 \text { 2SLS } \\
\text { Continuous }\end{array}$ & $\begin{array}{c}2 \text { 2SLS } \\
\text { Categorical }\end{array}$ \\
\hline & (1) & (2) & (3) & (4) & (5) & (6) \\
\hline Years of Schooling & $\begin{array}{c}0.075 * * * \\
(0.001)\end{array}$ & $\begin{array}{c}0.177 * * * \\
(0.035)\end{array}$ & $\begin{array}{c}0.070 * * * \\
(0.016)\end{array}$ & $\begin{array}{c}0.064 * * * \\
(0.001)\end{array}$ & $\begin{array}{c}0.135 * * * \\
(0.031)\end{array}$ & $\begin{array}{c}0.058 * * * \\
(0.017)\end{array}$ \\
\hline First Stage F-Stat & & 22.9 & 29.0 & & 19.3 & 19.9 \\
\hline $\mathrm{N}$ & $10,606,026$ & $10,606,026$ & $10,606,026$ & $6,871,341$ & $6,871,341$ & $6,871,341$ \\
\hline
\end{tabular}

Notes: Each column in the table presents the results of a separate regression using individuals who were born between 1885 and 1912, inclusive outside of the U.S. South. Results are shown for two samples of men nonSouthern Born white men: all white men who reported positive earnings and positive weeks worked in 1939 (Columns 1-3), and all white men who reported positive earnings and worked at least 40 weeks in 1939, works but is not self-employed, and did not live on a farm (Columns 4-6). We present OLS estimates of the returns to schooling (Columns 1 and 4), IV estimates of the returns to schooling using a single continuous measure of required years of schooling that includes continuation schooling requirements (Columns 2 and 5) and IV estimates of the returns to schooling using indicators for required years of schooling that includes continuation schooling requirements (Columns 3 and 6). The corresponding first stage estimates are found in Table 3. Each regression includes state of birth and region by year of birth fixed effects. Standard errors are clustered by state and year. Significance is represented by $* * *$ at the .01 level, $* *$ at the .05 level, and $*$ at the .10 level. 


\section{Appendix: For Online Publication}

\section{Appendix Figure 1: Effect of the Laws on Completed Schooling - Separate Continuation School}

\section{Panel A: Compulsory Attendance Requirements}

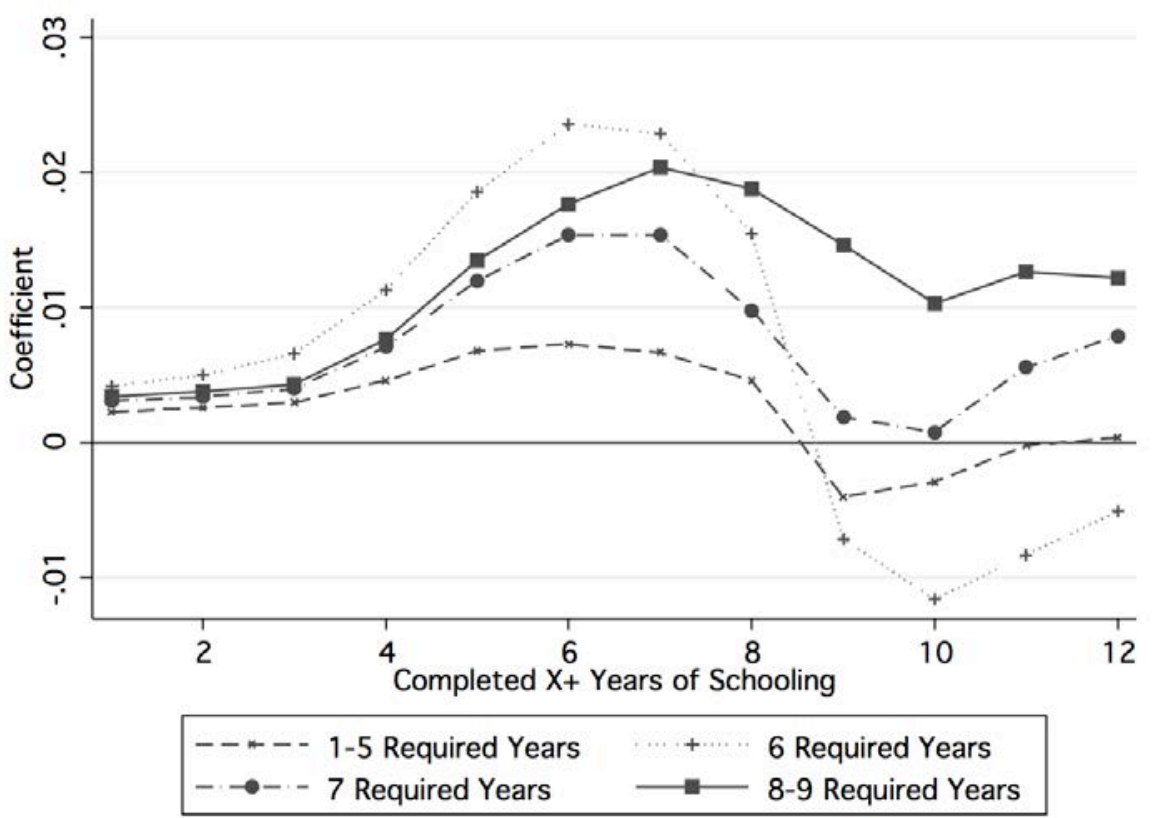

Panel B: Continuation School Requirements

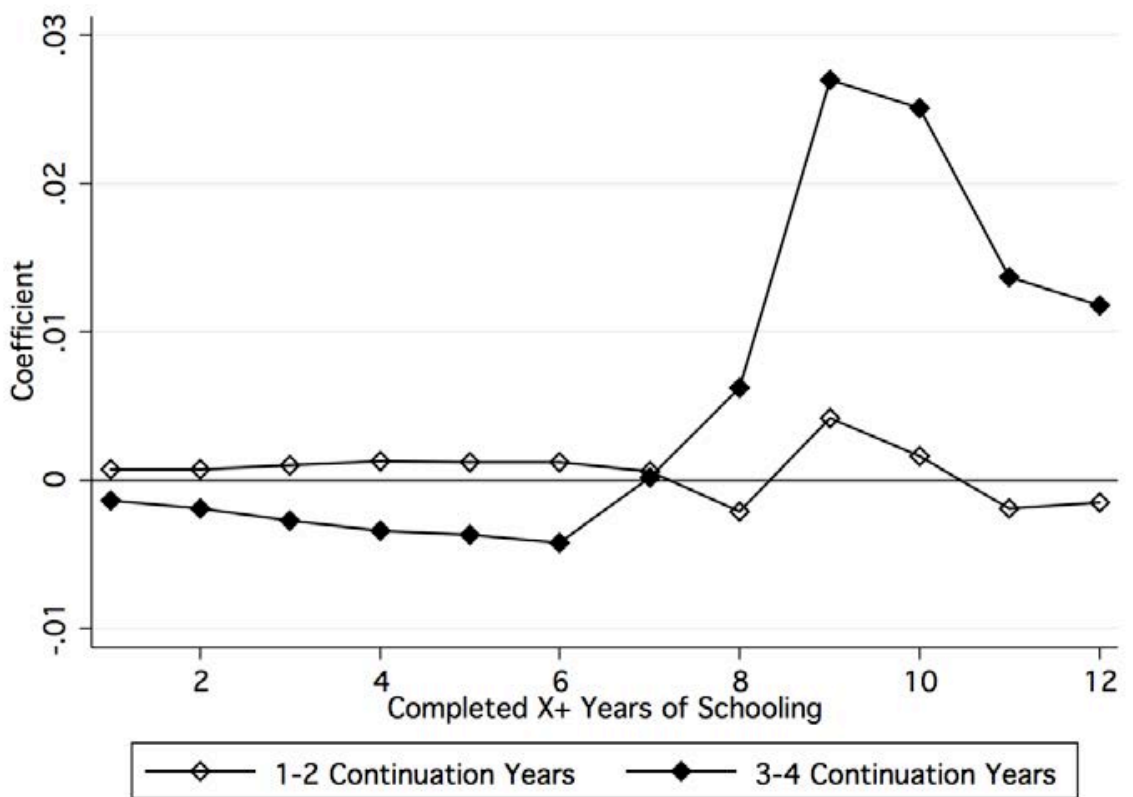

Notes: Figures show the coefficients from regressing completed years of schooling on laws using individuals who were born between 1885 and 1912, inclusive. The outcome in each regression is a binary indicator for having completed at least as many years as shown on the axes. Results are shown for the all white men sample that has $18,887,147$ observations. Each regression includes state of birth and region by year of birth fixed effects. See Appendix Table 2 for complete results. 
Appendix Table 1: Effect of the Laws on Completed Years of Schooling

\begin{tabular}{|c|c|c|c|c|c|c|c|c|c|c|c|c|}
\hline $\begin{array}{l}\text { VARIABLES } \\
\text { Years of Schooling }\end{array}$ & $\begin{array}{l}\text { Years of } \\
\text { School } \\
1+ \\
(1)\end{array}$ & $\begin{array}{l}\text { Years of } \\
\text { School } \\
2+ \\
(2)\end{array}$ & $\begin{array}{l}\text { Years of } \\
\text { School } \\
3+ \\
(3)\end{array}$ & $\begin{array}{l}\text { Years of } \\
\text { School } \\
4+ \\
(4)\end{array}$ & $\begin{array}{l}\text { Years of } \\
\text { School } \\
5+ \\
(5)\end{array}$ & $\begin{array}{l}\text { Years of } \\
\text { School } \\
6+ \\
(6)\end{array}$ & $\begin{array}{l}\text { Years of } \\
\text { School } \\
7+ \\
(7)\end{array}$ & $\begin{array}{l}\text { Years of } \\
\text { School } \\
8+ \\
(8)\end{array}$ & $\begin{array}{l}\text { Years of } \\
\text { School } \\
9+ \\
(9)\end{array}$ & $\begin{array}{l}\text { Years of } \\
\text { School } \\
10+ \\
(10)\end{array}$ & $\begin{array}{l}\text { Years of } \\
\text { School } \\
11+ \\
(11)\end{array}$ & $\begin{array}{l}\text { Years of } \\
\text { School } \\
12+ \\
(12)\end{array}$ \\
\hline \multicolumn{13}{|l|}{ Required Schooling: } \\
\hline One to Five Years & $\begin{array}{l}0.0025 * * * \\
(0.0006)\end{array}$ & $\begin{array}{l}0.0028 * * * \\
(0.0008)\end{array}$ & $\begin{array}{l}0.0034 * * * \\
(0.0010)\end{array}$ & $\begin{array}{l}0.0052 * * * \\
(0.0015)\end{array}$ & $\begin{array}{l}0.0074 * * * \\
(0.0024)\end{array}$ & $\begin{array}{l}0.0081 * * * \\
(0.0030)\end{array}$ & $\begin{array}{l}0.0074 * * \\
(0.0033)\end{array}$ & $\begin{array}{l}0.0048 \\
(0.0031)\end{array}$ & $\begin{array}{l}-0.0030 \\
(0.0024)\end{array}$ & $\begin{array}{l}-0.0028 \\
(0.0023)\end{array}$ & $\begin{array}{l}-0.0011 \\
(0.0023)\end{array}$ & $\begin{array}{l}-0.0005 \\
(0.0021)\end{array}$ \\
\hline Six Years & $\begin{array}{l}0.0046 * * * \\
(0.0007)\end{array}$ & $\begin{array}{l}0.00565 * * \\
(0.0008)\end{array}$ & $\begin{array}{l}0.0074 * * * \\
(0.0012)\end{array}$ & $\begin{array}{l}0.0123 * * * \\
(0.0018)\end{array}$ & $\begin{array}{l}0.0196 * * * \\
(0.0028)\end{array}$ & $\begin{array}{l}0.0245 * * * \\
(0.0035)\end{array}$ & $\begin{array}{l}0.0227 * * * \\
(0.0039)\end{array}$ & $\begin{array}{l}0.0138 * * * \\
(0.0037)\end{array}$ & $\begin{array}{l}-0.0094 * * * \\
(0.0030)\end{array}$ & $\begin{array}{l}-0.0144 * * * \\
(0.0027)\end{array}$ & $\begin{array}{l}-0.0117 * * * \\
(0.0026)\end{array}$ & $\begin{array}{l}-0.0081 * * * \\
(0.0023)\end{array}$ \\
\hline Seven Years & $\begin{array}{l}0.0037 * * * \\
(0.0008)\end{array}$ & $\begin{array}{l}0.0042 * * * \\
(0.0010)\end{array}$ & $\begin{array}{l}0.0053 * * * \\
(0.0013)\end{array}$ & $\begin{array}{l}0.0094 * * * \\
(0.0019)\end{array}$ & $\begin{array}{l}0.0155^{* * * *} \\
(0.0030)\end{array}$ & $\begin{array}{l}0.0208 * * * \\
(0.0037)\end{array}$ & $\begin{array}{l}0.0211 * * * \\
(0.0041)\end{array}$ & $\begin{array}{l}0.0128 * * * \\
(0.0039)\end{array}$ & $\begin{array}{l}0.0035 \\
(0.0034)\end{array}$ & $\begin{array}{l}-0.0021 \\
(0.0031)\end{array}$ & $\begin{array}{c}0.0004 \\
(0.0029)\end{array}$ & $\begin{array}{l}0.0027 \\
(0.0027)\end{array}$ \\
\hline Eight Years & $\begin{array}{l}0.0048 * * * \\
(0.0009)\end{array}$ & $\begin{array}{l}0.0055 * * * \\
(0.0010)\end{array}$ & $\begin{array}{l}0.0072 * * * \\
(0.0014)\end{array}$ & $\begin{array}{l}0.0128 * * * \\
(0.0020)\end{array}$ & $\begin{array}{l}0.0212 * * * \\
(0.0031)\end{array}$ & $\begin{array}{l}0.0283 * * * \\
(0.0038)\end{array}$ & $\begin{array}{l}0.0293 * * * \\
(0.0044)\end{array}$ & $\begin{array}{l}0.0191 * * * \\
(0.0042)\end{array}$ & $\begin{array}{l}0.0029 \\
(0.0039)\end{array}$ & $\begin{array}{l}-0.0063^{*} \\
(0.0033)\end{array}$ & $\begin{array}{l}-0.0052^{*} \\
(0.0031)\end{array}$ & $\begin{array}{l}-0.0015 \\
(0.0029)\end{array}$ \\
\hline Nine to Ten Years & $\begin{array}{l}0.0039 * * * \\
(0.0010)\end{array}$ & $\begin{array}{l}0.0042 * * * \\
(0.0012)\end{array}$ & $\begin{array}{l}0.0052 * * \\
(0.0017)\end{array}$ & $\begin{array}{l}0.0094 * * * \\
(0.0024)\end{array}$ & $\begin{array}{l}0.0150 * * * \\
(0.0034)\end{array}$ & $\begin{array}{l}0.0211 * * * \\
(0.0041)\end{array}$ & $\begin{array}{l}0.0258 * * * \\
(0.0047)\end{array}$ & $\begin{array}{l}0.0223 * * * \\
(0.0047)\end{array}$ & $\begin{array}{l}0.0467 * * * \\
(0.0056)\end{array}$ & $\begin{array}{l}0.0320 * * * \\
(0.0050)\end{array}$ & $\begin{array}{l}0.0184 * * \\
(0.0044)\end{array}$ & $\begin{array}{l}0.0156^{* * *} \\
(0.0040)\end{array}$ \\
\hline
\end{tabular}

Notes: Each column in the table presents the results of a separate regression using individuals who were born between 1885 and 1912 , inclusive. The outcome in each regression is a binary indicator for having completed at least as many years as shown at the top of the column. Results are shown for the all white men sample that has 18,887,147 observations. Each regression includes state of birth and region by year of birth fixed effects. Standard errors are clustered by state and year. Significance is represented by $* * *$ at the .01 level, $* *$ at the .05 level, and * at the .10 level. 
Appendix Table 2: Effect of the Laws on Completed Years of Schooling - Separate Continuation School

\begin{tabular}{|c|c|c|c|c|c|c|c|c|c|c|c|c|}
\hline $\begin{array}{l}\text { VARIABLES } \\
\text { Years of Schooling }\end{array}$ & $\begin{array}{l}\text { Years of } \\
\text { School } \\
1+ \\
(1)\end{array}$ & $\begin{array}{l}\text { Years of } \\
\text { School } \\
2+ \\
(2)\end{array}$ & $\begin{array}{l}\text { Years of } \\
\text { School } \\
3+ \\
(3)\end{array}$ & $\begin{array}{l}\text { Years of } \\
\text { School } \\
4+ \\
(4)\end{array}$ & $\begin{array}{l}\text { Years of } \\
\text { School } \\
5+ \\
(5)\end{array}$ & $\begin{array}{l}\text { Years of } \\
\text { School } \\
6+ \\
(6)\end{array}$ & $\begin{array}{l}\text { Years of } \\
\text { School } \\
7+ \\
(7)\end{array}$ & $\begin{array}{l}\text { Years of } \\
\text { School } \\
8+ \\
(8)\end{array}$ & $\begin{array}{l}\text { Years of } \\
\text { School } \\
9+ \\
(9)\end{array}$ & $\begin{array}{l}\text { Years of } \\
\text { School } \\
10+ \\
(10)\end{array}$ & $\begin{array}{l}\text { Years of } \\
\text { School } \\
11+ \\
(11)\end{array}$ & $\begin{array}{l}\text { Years of } \\
\text { School } \\
12+ \\
(12)\end{array}$ \\
\hline \multicolumn{13}{|l|}{$\begin{array}{l}\text { Required Schooling } \\
\text { w/o Continuation Yrs.: }\end{array}$} \\
\hline One to Five Years & $\begin{array}{l}0.0023 * * * \\
(0.0006)\end{array}$ & $\begin{array}{l}0.0026 * * * \\
(0.0008)\end{array}$ & $\begin{array}{l}0.0030 * * * \\
(0.0010)\end{array}$ & $\begin{array}{l}0.0046 * * * \\
(0.0015)\end{array}$ & $\begin{array}{l}0.0068 * * * \\
(0.0024)\end{array}$ & $\begin{array}{l}0.0073 * * * \\
(0.0029)\end{array}$ & $\begin{array}{l}0.0067 * * \\
(0.0032)\end{array}$ & $\begin{array}{l}0.0046 \\
(0.0030)\end{array}$ & $\begin{array}{l}-0.0040 \\
(0.0027)\end{array}$ & $\begin{array}{l}-0.0029 \\
(0.0024)\end{array}$ & $\begin{array}{l}-0.0002 \\
(0.0022)\end{array}$ & $\begin{array}{l}0.0004 \\
(0.0020)\end{array}$ \\
\hline Six Years & $\begin{array}{l}0.0042 * * * \\
(0.0007)\end{array}$ & $\begin{array}{l}0.0050 * * * \\
(0.0009)\end{array}$ & $\begin{array}{l}0.0066^{* * *} \\
(0.0012)\end{array}$ & $\begin{array}{l}0.0113 * * * \\
(0.0018)\end{array}$ & $\begin{array}{l}0.0186 * * * \\
(0.0028)\end{array}$ & $\begin{array}{l}0.0236 * * * \\
(0.0034)\end{array}$ & $\begin{array}{l}0.0229 * * * \\
(0.0038)\end{array}$ & $\begin{array}{l}0.0155^{* * *} \\
(0.0036)\end{array}$ & $\begin{array}{l}-0.0071 * * \\
(0.0033)\end{array}$ & $\begin{array}{l}-0.0116^{* * *} \\
(0.0029)\end{array}$ & $\begin{array}{l}-0.0083^{* * *} \\
(0.0025)\end{array}$ & $\begin{array}{l}-0.0051 * * \\
(0.0022)\end{array}$ \\
\hline Seven Years & $\begin{array}{l}0.0031 \text { *** } \\
(0.0008)\end{array}$ & $\begin{array}{l}0.0034 * * * \\
(0.0010)\end{array}$ & $\begin{array}{l}0.0040 * * * \\
(0.0014)\end{array}$ & $\begin{array}{l}0.0071 \text { *** } \\
(0.0021)\end{array}$ & $\begin{array}{l}0.0120 * * * \\
(0.0032)\end{array}$ & $\begin{array}{l}0.0154 * * * \\
(0.0039)\end{array}$ & $\begin{array}{l}0.0154 * * * \\
(0.0039)\end{array}$ & $\begin{array}{l}0.0098 * * \\
(0.0040)\end{array}$ & $\begin{array}{l}0.0019 \\
(0.0039)\end{array}$ & $\begin{array}{l}0.0008 \\
(0.0035)\end{array}$ & $\begin{array}{l}0.0056^{*} \\
(0.0031)\end{array}$ & $\begin{array}{l}0.0079 * * * \\
(0.0029)\end{array}$ \\
\hline Eight to Nine Years & $\begin{array}{l}0.0034 * * * \\
(0.0010)\end{array}$ & $\begin{array}{l}0.0038 * * * \\
(0.0012)\end{array}$ & $\begin{array}{l}0.0043 * * * \\
(0.0016)\end{array}$ & $\begin{array}{l}0.0077 * * * \\
(0.0022)\end{array}$ & $\begin{array}{l}0.0135 * * * \\
(0.0034)\end{array}$ & $\begin{array}{l}0.0177 * * * \\
(0.0042)\end{array}$ & $\begin{array}{l}0.0204 * * * \\
(0.0047)\end{array}$ & $\begin{array}{l}0.0188 * * * \\
(0.0044)\end{array}$ & $\begin{array}{l}0.0146 * * * \\
(0.0047)\end{array}$ & $\begin{array}{l}0.0103 * * \\
(0.0041)\end{array}$ & $\begin{array}{l}0.0127 * * * \\
(0.0036)\end{array}$ & $\begin{array}{l}0.0122 * * * \\
(0.0033)\end{array}$ \\
\hline \multicolumn{13}{|l|}{$\begin{array}{l}\text { Continuation } \\
\text { School: }\end{array}$} \\
\hline One to Two Years & $\begin{array}{l}0.0007 * * * \\
(0.0003)\end{array}$ & $\begin{array}{l}0.0007 * \\
(0.0004)\end{array}$ & $\begin{array}{l}0.0010^{*} \\
(0.0005)\end{array}$ & $\begin{array}{l}0.0013^{*} \\
(0.0008)\end{array}$ & $\begin{array}{l}0.0012 \\
(0.0011)\end{array}$ & $\begin{array}{l}0.0012 \\
(0.0015)\end{array}$ & $\begin{array}{l}0.0006 \\
(0.0016)\end{array}$ & $\begin{array}{l}-0.0021 \\
(0.0016)\end{array}$ & $\begin{array}{l}0.0042 \\
(0.0026)\end{array}$ & $\begin{array}{l}0.0016 \\
(0.0023)\end{array}$ & $\begin{array}{l}-0.0019 \\
(0.0020)\end{array}$ & $\begin{array}{l}-0.0015 \\
(0.0018)\end{array}$ \\
\hline Three to Four Years & $\begin{array}{l}-0.0014 * * * \\
(0.0003)\end{array}$ & $\begin{array}{l}-0.0019 * * * \\
(0.0004)\end{array}$ & $\begin{array}{l}-0.0027 * * * \\
(0.0007)\end{array}$ & $\begin{array}{l}-0.0034 * * * \\
(0.0009)\end{array}$ & $\begin{array}{l}-0.0037 * * \\
(0.0014)\end{array}$ & $\begin{array}{l}-0.0042 * * \\
(0.0018)\end{array}$ & $\begin{array}{l}0.0002 \\
(0.0021)\end{array}$ & $\begin{array}{l}0.0062 * * * \\
(0.0020)\end{array}$ & $\begin{array}{l}0.0270 * * * \\
(0.0033)\end{array}$ & $\begin{array}{l}0.0251 * * * \\
(0.0031)\end{array}$ & $\begin{array}{l}0.0137 * * * \\
(0.0027)\end{array}$ & $\begin{array}{l}0.0118 * * * \\
(0.0025)\end{array}$ \\
\hline
\end{tabular}

Notes: Each column in the table presents the results of a separate regression using individuals who were born between 1885 and 1912 , inclusive. The outcome in each regression is a binary indicator for having completed at least as many years as shown at the top of the column. Results are shown for the all white men sample that has 18,887,147 observations. Each regression includes state of birth and region by year of birth fixed effects. Standard errors are clustered by state and year. Significance is represented by $* * *$ at the .01 level, $* *$ at the .05 level, and $*$ at the .10 level. 
Appendix Table 3: Reduced Form Estimates of Returns to Schooling

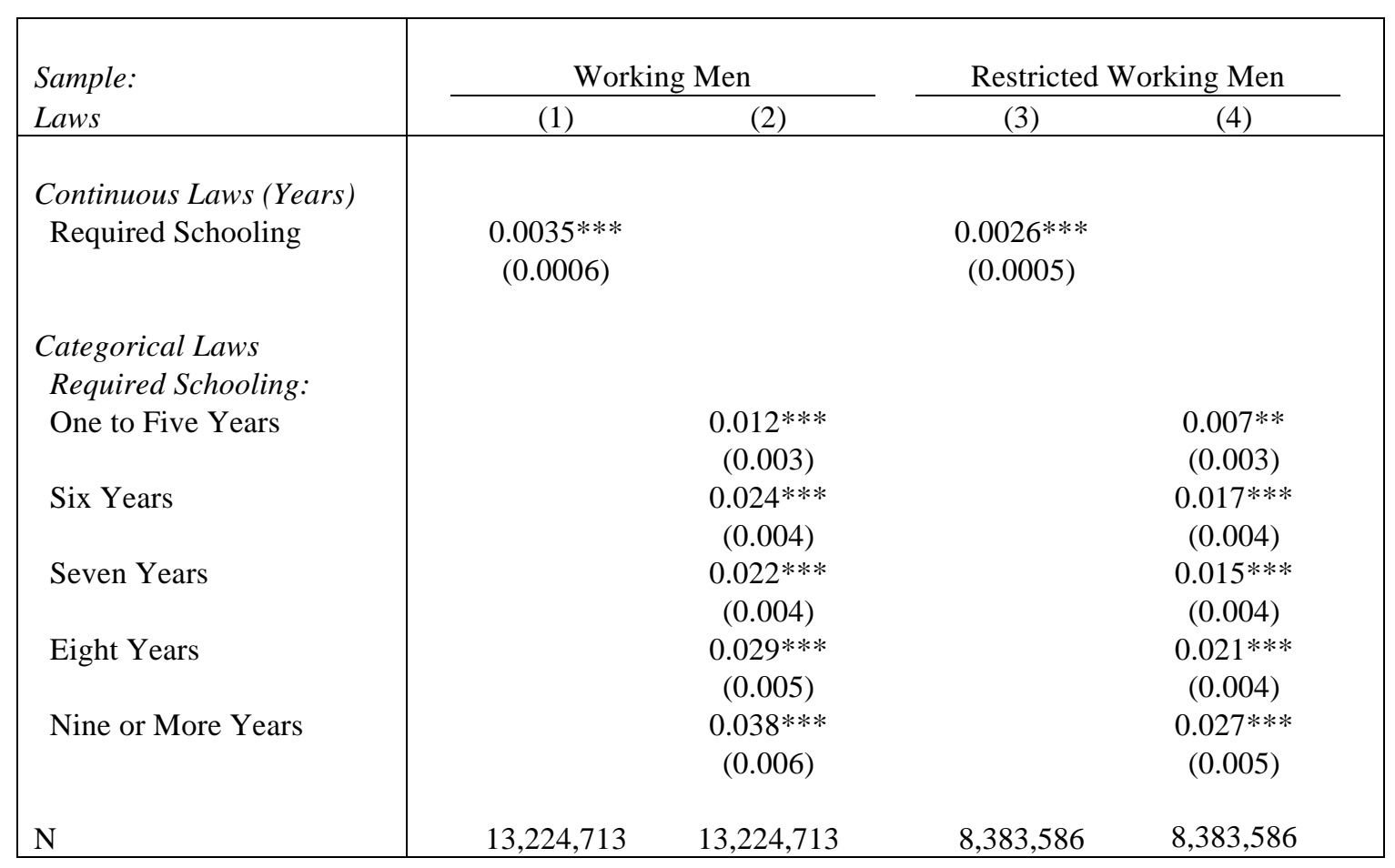

Notes: See notes to Table 4. We restrict the analysis to men working in 1939 who were born between 1885 and 1912 . The instruments are the years of required compulsory attendance and continuation school indicators used in Table 7, Column 4 (Columns 1-4 here), and Table 8, Column 4 (Columns 5-8 here). Each regression includes state of birth and region by year of birth fixed effects. Significance is represented by *** at the .01 level, ** at the .05 level, and * at the .10 level. 
Appendix Table 4: Impact of Education on Earnings - 1\% Sample of 1940 Census

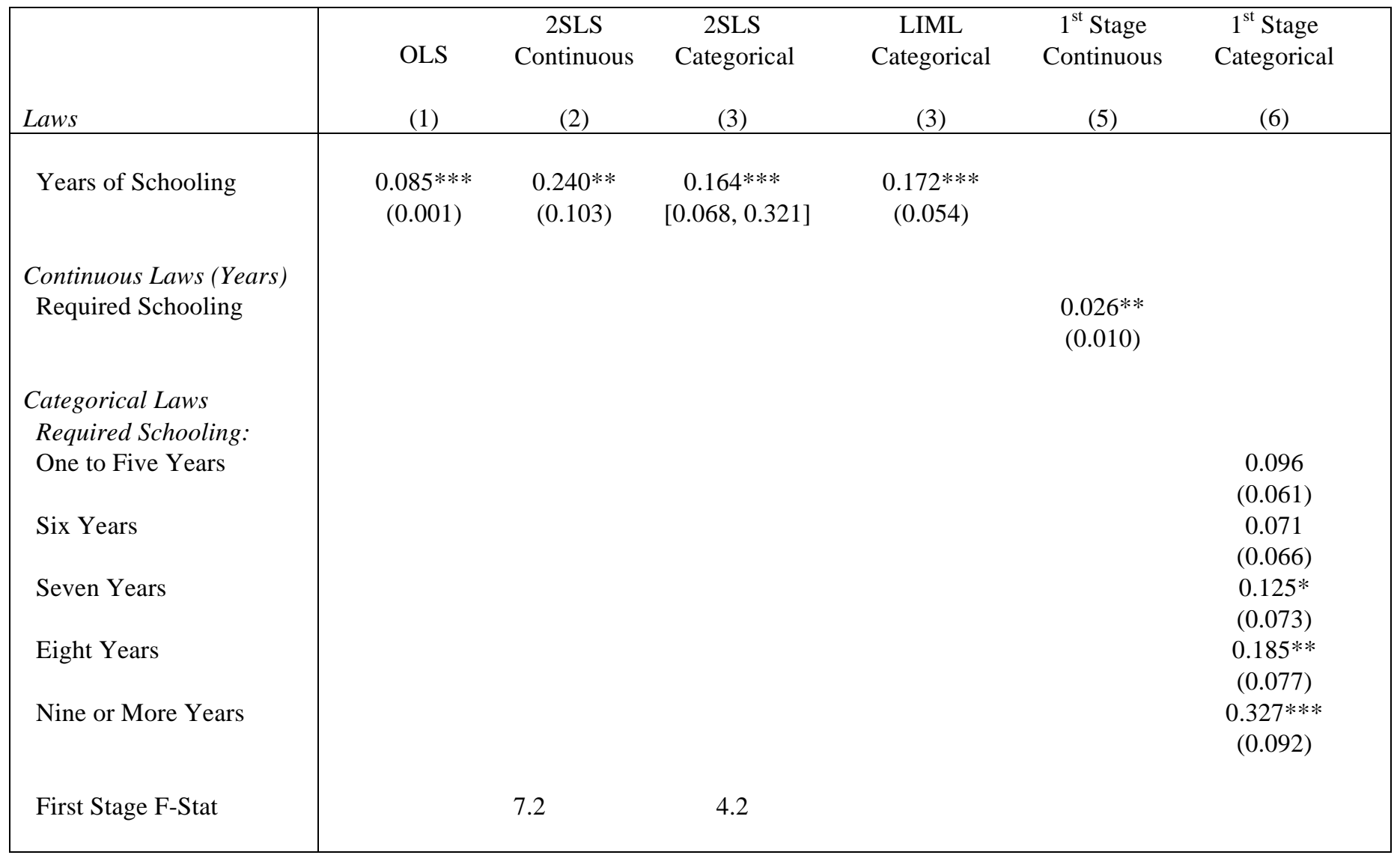

Notes: Each column in the table presents the results of a separate regression using individuals who were born between 1885 and 1912 , inclusive. Results are shown for the previously available $1 \%$ micro sample of the 1940 Census constructed using the same criteria as the working men sample: all white men who reported positive earnings and positive weeks worked in 1939. This sample contains 142,173 observations. Each regression includes state of birth and region by year of birth fixed effects. Standard errors are clustered by state and year and are shown in parentheses. 95\% confidence intervals for Moreira's Conditional Likelihood Ratio Test are shown in brackets. Significance is represented by *** at the .01 level, ** at the .05 level, and * at the .10 level. 
Appendix Table 5: Quantile Instrumental Variable Regression Estimates of Returns to Schooling

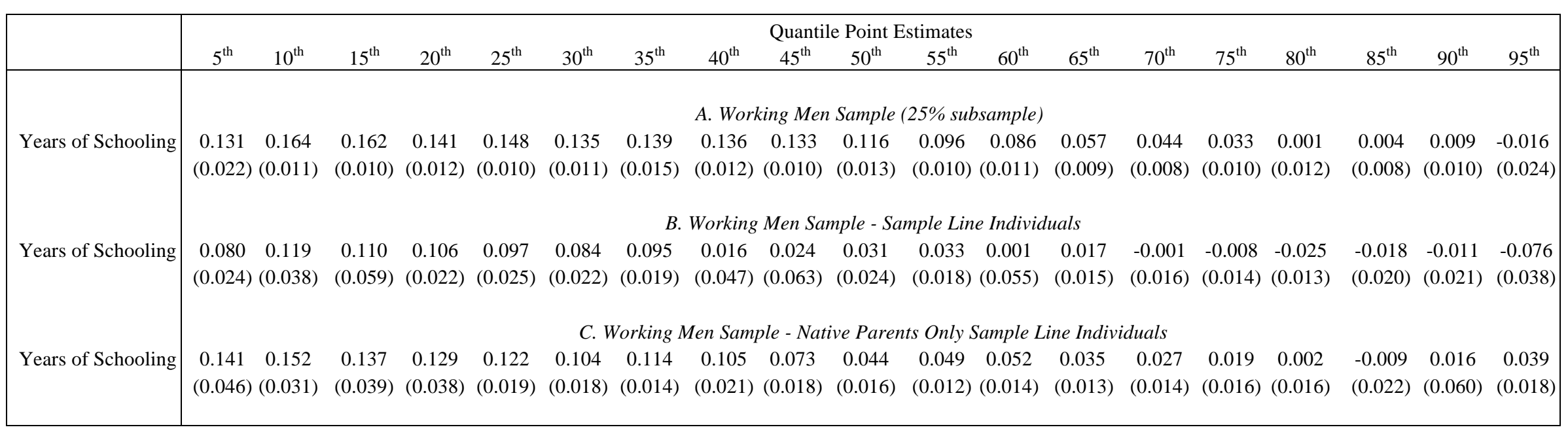

Notes: Each estimate in the table presents the results of a separate quantile IV regression of log weekly wages on years of schooling, using laws as an instrument for years of schooling. We restrict the analysis to men working in 1939 who were born between 1885 and 1912. Results are shown from the working men sample: all white men who reported positive earnings and positive weeks worked in 1939. Panel A uses a random $25 \%$ sample of the working men sample and contains 3,306,178 observations. Panel B uses the 638,239 observations from the full working men sample who are sample line individuals. Panel C uses the 471,363 observations from the full working men sample who are sample line individuals and have both parents that are native born. The instruments are the combined years of required compulsory attendance and continuation school indicators used in Table 3, Columns 2,4, and 6. Each regression includes state of birth and region by year of birth fixed effects. 
Appendix Table 6: Effect of the Laws on Years of Schooling on Those with Foreign-born Parents - Categorical Laws

\begin{tabular}{|c|c|c|c|c|c|c|}
\hline \multirow{2}{*}{$\begin{array}{l}\text { Sample: } \\
\text { Sample: } \\
\text { Laws }\end{array}$} & Full Sample & \multicolumn{4}{|c|}{ Outcome $=$ Years of Schooling } & \\
\hline & $\begin{array}{l}\text { All } \\
(1) \\
\end{array}$ & $(2)$ & $\begin{array}{l}\text { All } \\
(3) \\
\end{array}$ & $(4)$ & $\begin{array}{c}\begin{array}{c}\text { Parents } \\
\text { Native-born }\end{array} \\
(5)\end{array}$ & $\begin{array}{l}1+\text { Parent(s) } \\
\text { Foreign-born } \\
(6)\end{array}$ \\
\hline One to Five Years & $\begin{array}{c}0.039 * * \\
(0.017)\end{array}$ & $\begin{array}{c}0.027 \\
(0.031)\end{array}$ & $\begin{array}{c}0.028 \\
(0.031)\end{array}$ & $\begin{array}{c}0.030 \\
(0.037)\end{array}$ & $\begin{array}{c}0.051 \\
(0.033)\end{array}$ & $\begin{array}{l}-0.104 \\
(0.072)\end{array}$ \\
\hline Six Years & $\begin{array}{c}0.045 * * \\
(0.021)\end{array}$ & $\begin{array}{c}0.028 \\
(0.036)\end{array}$ & $\begin{array}{c}0.027 \\
(0.035)\end{array}$ & $\begin{array}{c}0.038 \\
(0.042)\end{array}$ & $\begin{array}{c}0.095 * * \\
(0.038)\end{array}$ & $\begin{array}{c}-0.184 * * \\
(0.073)\end{array}$ \\
\hline Seven Years & $\begin{array}{c}0.094 * * * \\
(0.022)\end{array}$ & $\begin{array}{c}0.104 * * * \\
(0.039)\end{array}$ & $\begin{array}{c}0.106 * * * \\
(0.038)\end{array}$ & $\begin{array}{c}0.127 * * * \\
(0.044)\end{array}$ & $\begin{array}{c}0.160 * * * \\
(0.042)\end{array}$ & $\begin{array}{c}-0.074 \\
(0.075)\end{array}$ \\
\hline Eight Years & $\begin{array}{c}0.123^{* * * *} \\
(0.024)\end{array}$ & $\begin{array}{c}0.122 * * * \\
(0.041)\end{array}$ & $\begin{array}{c}0.129 * * * \\
(0.040)\end{array}$ & $\begin{array}{c}0.141 * * * \\
(0.046)\end{array}$ & $\begin{array}{c}0.182 * * * \\
(0.043)\end{array}$ & $\begin{array}{l}-0.047 \\
(0.078)\end{array}$ \\
\hline Nine or More Years & $\begin{array}{c}0.246 * * \\
(0.029)\end{array}$ & $\begin{array}{c}0.255^{* * *} * \\
(0.047)\end{array}$ & $\begin{array}{c}0.288 * * * \\
(0.047)\end{array}$ & $\begin{array}{c}0.261 * * * \\
(0.052)\end{array}$ & $\begin{array}{c}0.377 * * * \\
(0.051)\end{array}$ & $\begin{array}{c}0.045 \\
(0.088)\end{array}$ \\
\hline Foreign-born Parent & & & $\begin{array}{c}-0.602 * * * \\
(0.019)\end{array}$ & $\begin{array}{c}-0.547 * * * \\
(0.161)\end{array}$ & & \\
\hline One to Five Years & & & & $\begin{array}{c}-0.013 \\
(0.191)\end{array}$ & & \\
\hline Six Years & & & & $\begin{array}{c}-0.073 \\
(0.166)\end{array}$ & & \\
\hline Seven Years & & & & $\begin{array}{c}-0.094 \\
(0.163)\end{array}$ & & \\
\hline Eight Years & & & & $\begin{array}{l}-0.065 \\
(0.163)\end{array}$ & & \\
\hline Nine or More Years & & & & $\begin{array}{c}0.074 \\
(0.163)\end{array}$ & & \\
\hline $\mathrm{N}$ & $18,887,147$ & 905,796 & 905,796 & 905,796 & 674,139 & 231,657 \\
\hline
\end{tabular}

Notes: Each column in the table presents the results of a separate regression using individuals who were born between 1885 and 1912 , inclusive. See notes to Table 5. 


\section{Appendix Table 7: Impact of Education on Earnings - 25\% Working Men Sample}

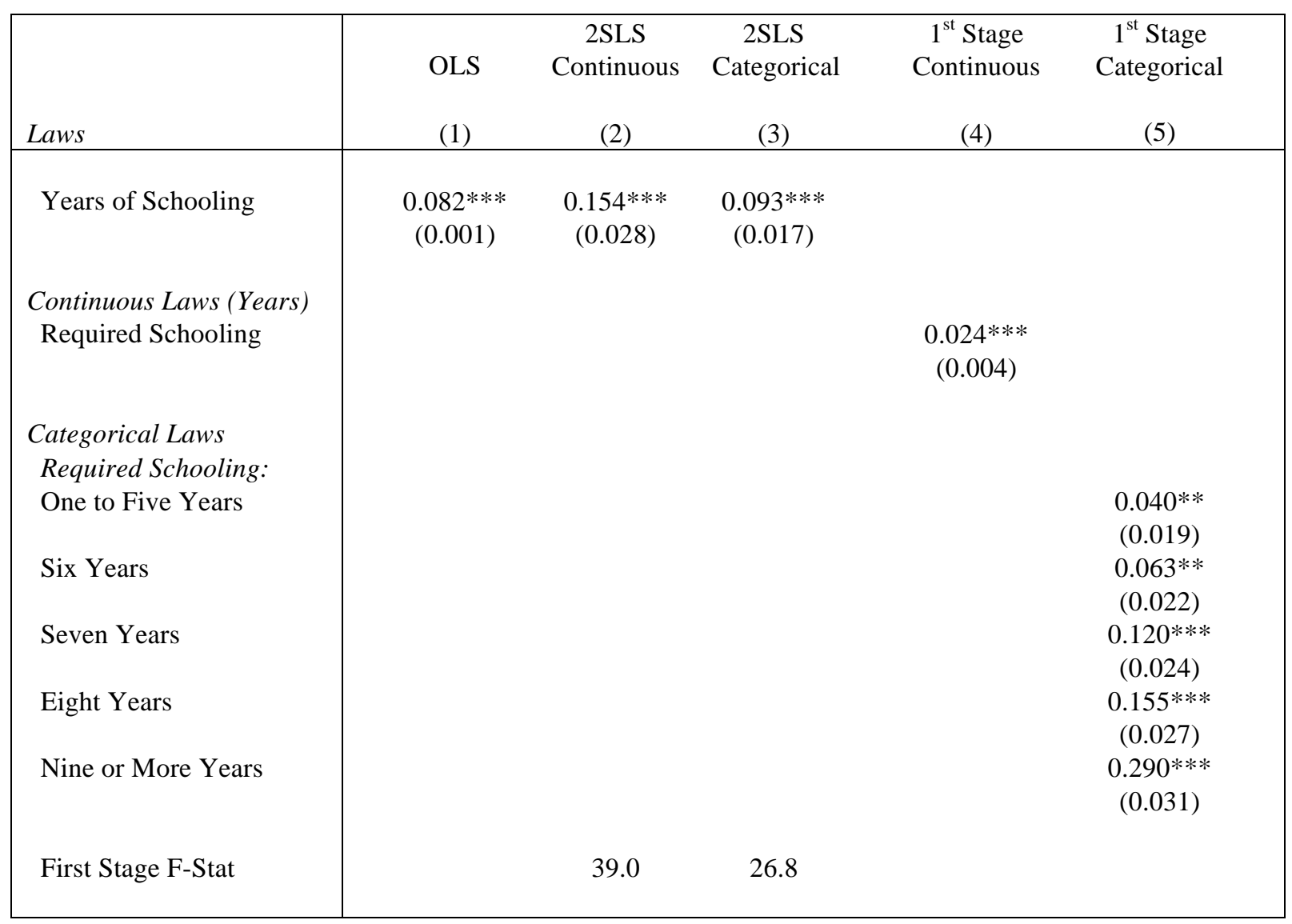

Notes: Each column in the table presents the results of a separate regression using individuals who were born between 1885 and 1912, inclusive. Results are shown for a random 25\% sample of the working men sample: all white men who reported positive earnings and positive weeks worked in 1939. This sample, which is the same sample that is used in the quantile IV estimates shown in Figure 5 and Panel A of Appendix Table 4, contains 3,306,178 observations. Each regression includes state of birth and region by year of birth fixed effects. Standard errors are clustered by state and year. Significance is represented by $* * *$ at the .01 level, $* *$ at the .05 level, and $*$ at the .10 level. 


\section{Appendix Table 8: Impact of Schooling on Employment Outcomes}

\begin{tabular}{|c|c|c|c|c|c|}
\hline \multirow[b]{2}{*}{ Outcome: } & \multicolumn{5}{|c|}{ Panel A: OLS Estimates } \\
\hline & Employed & $\begin{array}{l}\text { Employed } \\
\text { Excl. WPA }\end{array}$ & Unemployed & $\begin{array}{l}\text { Unemployed } \\
\text { Incl. WPA }\end{array}$ & $\begin{array}{l}\text { Not in the } \\
\text { Labor Force }\end{array}$ \\
\hline Mean of Dep Var.: & 0.886 & 0.842 & 0.063 & 0.109 & 0.055 \\
\hline Laws & (1) & (2) & (3) & (4) & (5) \\
\hline Years of Schooling & $\begin{array}{c}0.010 * * * \\
(0.0001)\end{array}$ & $\begin{array}{c}0.017 * * * \\
(0.0001)\end{array}$ & $\begin{array}{c}-0.006^{* * *} * \\
(0.0001)\end{array}$ & $\begin{array}{c}-0.013 * * * \\
(0.0001)\end{array}$ & $\begin{array}{c}-0.005 * * * \\
(0.0001)\end{array}$ \\
\hline & \multicolumn{5}{|c|}{ Panel B: 2SLS Estimates } \\
\hline Outcome: & Employed & $\begin{array}{l}\text { Employed } \\
\text { Excl. WPA }\end{array}$ & Unemployed & $\begin{array}{l}\text { Unemployed } \\
\text { Incl. WPA }\end{array}$ & $\begin{array}{l}\text { Not in the } \\
\text { Labor Force }\end{array}$ \\
\hline Laws & (1) & (2) & (3) & (4) & (5) \\
\hline Years of Schooling & $\begin{array}{c}0.012 * * * \\
(0.004)\end{array}$ & $\begin{array}{c}0.027 * * * \\
(0.005)\end{array}$ & $\begin{array}{c}-0.013 * * * \\
(0.003)\end{array}$ & $\begin{array}{c}-0.028 * * * \\
(0.005)\end{array}$ & $\begin{array}{l}-0.0001 \\
(0.0024)\end{array}$ \\
\hline
\end{tabular}

Notes: Each estimate in the table presents the results of a separate regression using the sample of all white men who were born between 1885 and 1912, inclusive. We present OLS estimates in Panel A and 2SLS estimates in Panel B using the categorical instruments. The outcome in column (1) is an indicator for being employed during the week of March 24-30, 1940. The outcome in column (2) is an indicator for being employed but excluding those on work relief from counting as employed (Goldin and Margo 1992). The outcome in column (3) is an indicator for being unemployed but only uses those men who are participating in the labor force in the analysis. The analysis in column (4) is the same as that found in column (3) except those on work relief are counted as being unemployed (Goldin and Margo 1992). The outcome in column (5) is an indicator for being out of the labor force. The sample of 18,887,147 observations in columns (1), (2), and (5) includes all white men in the relevant birth cohorts. The sample of $17,853,124$ observations in columns (3) and (4) includes those who are in the labor force. The corresponding first stage estimates for columns (1), (2), and (5) are shown in column (2) of Table 2 and the corresponding first stage Fstatistic is 18.3. The first stage estimates and F-statistic for the sample of men in the labor force used in columns (3) and (4) is quite similar to the results combining men both in and out of the labor force. Each regression includes state of birth and region by year of birth fixed effects. Standard errors are clustered by state and year. Significance is represented by $* * *$ at the .01 level, $* *$ at the .05 level, and * at the .10 level. 


\title{
Data Appendix to Laws, Educational Outcomes, and Returns to Schooling: Evidence from the Early Twentieth Century United States Karen Clay, Jeff Lingwall, and Melvin Stephens Jr.
}

\author{
State-Level Compulsory Attendance, Child Labor, and Continuation Schooling Laws
}

The attached STATA file contains the compulsory attendance, child labor, and continuation school age limits and exemptions for each state between 1880 and 1930 . This builds on the work of many others, in particular Stephens and Yang (2014) and the 1910-1939 compilation in Goldin and Katz (2007), which expanded work by Angrist and Acemoglu (2000), Adriana Lleras-Muney, and Stephanie Schmidt. This dataset extends these previous codings to 1880 , but differs in some ways to accommodate additional characteristics of the laws.

The dataset has ten variables:

1. entryage: The age at which children had to enter school.

2. exitage: The age at which all children could stop attending school.

3. earlyyrs: The years of completed schooling that allowed an exemption to exitage.

4. earlyyrs_condition: The earliest age at which an earlyyrs exemption could be used. For example, the unconditional exit age might be 16 (exitage $=16$ ) with the ability to drop out after six years of schooling (earlyyrs $=6$ ), provided the child was at least 14 (earlyyrs_condition $=14$ ).

5. workage: The age at which employed children could stop attending school.

6. workyrs: The schooling required for a workage exception to apply.

7. contage: The age working children stopped attending continuation school. ${ }^{21}$

8. contyrs: The schooling required to be exempt from continuation school.

9. reference_agelimit: A reference to the state session law or statutory compilation in which the law is found. (With limited exceptions, the dates and age limits are drawn directly from the state session laws, which are accessible through HeinOnline's historical state law database.) For states with laws prior to 1880 , this references the source of the age limits existing in 1880.

10. reference_courseofstudy: A reference indicating the length of a typical primary school course when earlyyrs or workyrs required completion of primary school.

\footnotetext{
${ }^{21}$ States varied in the scope of their continuation schooling laws. Most states with these laws required the creation of continuation schools, contingent on city size or number of eligible children in the district. A minority of states in this time period-Connecticut (through 1918 outside large cities), Indiana, and Ohio (through 1921)_gave districts the option of creating schools and requiring attendance. The attached STATA file treats both types of law as requiring continuation school attendance.
} 
Most of the laws had exceptions for poverty, distance from school, or by special order of a local judge or school board. As with prior codings, we ignore these and other case-specific exemptions. When a law was optional at the county level, or passed county by county, we use the date the law either applied statewide or required counties to opt-out rather than opt-in. Where one age applied to cities and towns and another to the rest of the state, we use the age limit applicable to the state generally. These are complex laws, and special cases sometimes required discretionary coding. Details on initial laws in particular states are given below.

The variables earlyyrs, workyrs, and contyrs are coded as "99" when the laws required literacy rather than a specific number of years of school. When these variables used "completion of primary school" or similar language as the requirement, we code the law as " $99 \mathrm{X}$ ", where X is the length of a typical primary school course in the state.

\section{State-Specific Notes on Initial Laws}

Alabama We code the initial attendance law as beginning in 1917, because the 1915 statute specified the law would take effect "on and after the first day of October, 1917."22

Arizona An early attendance law was passed in 1875 , but was repealed in $1883 .^{23}$ The conventional date of the first law is 1899 , when the law was re-implemented. ${ }^{24}$

Arkansas We code the initial law as beginning in 1917, because an earlier 1909 law did not apply to 44 of 75 counties (including Pulaski County, the most populous county and location of Little Rock). ${ }^{25}$

Florida A 1915 law was an “opt in” law, which no county implemented prior to $1918 .^{26}$

Georgia We code the initial attendance law as beginning in 1917, because the 1916 statute specified "the provisions of this Act shall become operative on the first day of January in the year nineteen hundred and seventeen." 27

Louisiana A 1910 law applied only to the Parish of Orleans. ${ }^{28}$ In 1916 compulsory attendance was applied statewide. $^{29}$

${ }^{22} 1915$ Ala. Acts 534.

${ }^{23} 1883$ Ariz. Sess. Laws 50; 1875 Ariz. Sess. Laws 40.

241899 Ariz. Sess. Laws 14.

${ }^{25} 1909$ Ark. Acts 706.

${ }^{26} 1915$ Fla. Laws 61; Harry Garden CUtler, 1 History of FloridA, PAST ANd Present, HistoriCAL AND BIOGRAPHICAL 180 (1923) (noting the first county to adopt the law in 1918, and that by 1919 the law applied statewide).

271916 Ga. Laws 103.

${ }^{28} 1910$ La. Acts 366.

${ }^{29} 1916$ La. Acts 59. 
Mississippi A 1918 law was an "opt in" law, which was not effective. ${ }^{30}$ The 1920 law was an "opt out" law, and as of 1921 only four counties had opted out. ${ }^{31}$

North Carolina North Carolina passed compulsory attendance for a few select counties in 1901 and 1903, and in 1907 an "opt in" law was passed that applied across the state. ${ }^{32}$ As of 1910 the state reported that "[o]nly a few districts have as yet availed themselves of this law and adopted compulsory attendance." The 1913 law required attendance statewide. ${ }^{34}$

Tennessee In 1905, the state began to pass laws county by county through a tortured population-based method based on the 1900 census. ${ }^{35}$ In 1913 the law applied statewide. ${ }^{36}$

Texas An early compulsory attendance law was passed during the 1870 s, but was soon repealed. ${ }^{37}$

Compulsory attendance was revisited in 1915 , with a law that went into effect in $1916 .^{38}$

Virginia A 1908 law was "opt in," which was not widely adopted. ${ }^{39}$ The law was applied statewide in $1918 .^{40}$

Washington An initial statewide attendance law was passed in 1871 and repealed in $1873 .{ }^{41} \mathrm{~A}$ second attendance law was passed in 1877 , which did not apply to small localities. ${ }^{42}$ In 1886 the law applied statewide. $^{43}$

\section{Calculating Years of Required Schooling}

The required years of attendance for each birth cohort in each state can be calculated by iterating through the dataset. In each year of a child's life, this calculation asks whether

\footnotetext{
${ }^{30} 1918$ Miss. Laws 312; Biennial REPORT AND RECOMMENDATIONS OF THE STATE SuPERINTENDENT OF Public EduCATION to the Legislature OF MisSissipPI FOR the SCHOLASTIC YeARS 1919-1920 AND 1920-1921, at 11 (1921) (comparing 1920 to 1918).

${ }^{31} I d$.

321907 N.C. Sess. Laws 1284; 1903 N.C. Sess. Laws 1011, 1030, 1036, 1152; 1901 N.C. Sess. Laws 988.

${ }^{33}$ BIENNIAL REPORT OF THE SUPERINTENDENT OF PUbliC InSTRUCTION OF NORTH CAROLINA tO GOVERNOR W.W. KITCHIN FOR THE SCHOLASTIC YEARS 1908-1909 AND 1909-1910, at 44 (1910).

${ }^{34} 1913$ N.C. Sess. Laws 267.

${ }^{35}$ E.g., 1905 Tenn. Pub. Acts 1040 (implementing compulsory attendance in, e.g., "counties of this State having a population of no less than ... 12,890 ... and not more than ... 12,900, according to the Federal Census of 1900 ....").

${ }^{36} 1913$ Tenn. Pub. Acts 19.

${ }^{37} 1876$ Tex. Gen. Laws 199; 1870 Tex. Gen. Laws 113.

${ }^{38} 1915$ Tex. Gen. Laws 92 (noting the law would take require attendance "beginning September 1, 1916").

391908 Va. Acts 640; ANNUAL Report of the SuPERINTENDENT OF PUblic InSTRUCTION OF the COMmonwealth of Virginia With ACCOMPanYing Documents: School Year 1916-1917, at 57-118 (1918) (noting county-level implementation of compulsory attendance).

${ }^{40} 1918$ Va. Acts 752.

${ }^{41} 1873$ Wash. Sess. Laws 419; 1871 Wash. Sess. Laws 29.

${ }^{42} 1877$ Wash. Sess. Laws 278 (applying to "any city, town or village containing more than four hundred inhabitants").

${ }^{43} 1886$ Wash. Sess. Laws 27.
} 
attendance was required based on the laws in that year and the cohort's accumulated years of required attendance. Specifically, at each age 5 to 17 of a child's life, we ask

(1) Is the child's age between the entryage and the exitage in effect in that year?

(2) Does an exemption to exitage apply?

a. Has the child already been required to attend for sufficient years to qualify for an earlyyrs exemption? Or,

b. Is the child's age equal to or greater than the workage? If so, has the child been required to attend for sufficient years to satisfy the workyrs requirement?

(3) If a workage exemption applies, is the child's age less than contage? If so, has the child completed sufficient schooling to be exempt from continuation school if a contyrs exemption exists?

For example, Alabama passed its first compulsory attendance law in 1915, which went into effect in 1917. The law required attendance between ages 8 and 16 (entryage = 8 and exitage $=16$ ). In 1919, the state added an exception for children who had completed primary school (which took six years of schooling), so long as the child was at least 14 (earlyyrs = 996 and earlyyrs_condition =14). Children could also leave school to work at age 14, so long as they had a fourth-grade education (workage $=14$ and workyrs =4). The Table below highlights each year the 1902-1909 birth cohorts are coded as required to attend school. It also shows the total years of required schooling for a child in each cohort. 
Data Appendix Table 1: Attendance Requirements for the 1902-1909 Alabama Birth Cohorts

\begin{tabular}{|c|c|c|c|c|c|c|c|}
\hline \multicolumn{8}{|c|}{ Birth Cohort } \\
\hline 1902 & 1903 & 1904 & 1905 & 1906 & 1907 & 1908 & 1909 \\
\hline
\end{tabular}

Calendar Year

1916

1917 (first law in effect)

1918

1919 (law modified)

1920

1921

1922

1923

Years Required

Attendance:

1902

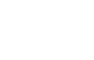

15

Cohort's Age in Each Year

$\begin{array}{rrrrrrrr}14 & 13 & 12 & 11 & 10 & 9 & 8 & 7 \\ 15 & \mathbf{1 4} & \mathbf{1 3} & \mathbf{1 2} & \mathbf{1 1} & \mathbf{1 0} & \mathbf{9} & \mathbf{8} \\ 16 & \mathbf{1 5} & \mathbf{1 4} & \mathbf{1 3} & \mathbf{1 2} & \mathbf{1 1} & \mathbf{1 0} & \mathbf{9} \\ 17 & 16 & \mathbf{1 5} & \mathbf{1 4} & \mathbf{1 3} & \mathbf{1 2} & \mathbf{1 1} & \mathbf{1 0} \\ 18 & 17 & 16 & \mathbf{1 5} & \mathbf{1 4} & \mathbf{1 3} & \mathbf{1 2} & \mathbf{1 1} \\ 19 & 18 & 17 & 16 & 15 & 14^{2} & \mathbf{1 3} & \mathbf{1 2} \\ 20 & 19 & 18 & 17 & 16 & 15 & 14 & \mathbf{1 3} \\ 21 & 20 & 19 & 18 & 17 & 16 & 15 & 14^{3}\end{array}$

12

3

4

4

4

5

6

Notes: A child is coded as required to attend school in each highlighted cell. The bottom row shows the total years of required attendance for each birth cohort.

${ }^{1}$ A child born in 1904 is coded as required to attend school in 1919, at age 15, despite the age 14 workage exemption, because they had not been required to complete the workyrs four years of schooling. Similarly, a child born in 1905 is coded as required to attend at ages 14 and 15, and a child born in 1906 is coded as required to attend at age 14 .

${ }^{2}$ A child born in 1907 was required to attend for four years (1917-1920), and so would qualify for the workage exemption at age 14 , in 1921.

${ }^{3}$ A child born in 1909 was required to attend six years of school (1917-1922, at ages 8-13). At age 14, the child would be exempt under the six years earlyyrs exemption. The child would also be exempt under the workage exemption, because they had more than four years of required attendance. 


\section{Example Compulsory Attendance Laws}

Oregon's 1889 compulsory attendance law ${ }^{44}$

Section 1. Every parent, guardian, or other person in this State having control or charge of a child or children between the ages of eight and fourteen years shall be required to send such child or children to a public school for a period of at least twelve weeks in each school year, of which at least eight weeks' school be consecutive, unless the bodily or mental condition of such child or children has been such as to prevent his or her or their attendance at school or application to study for the period required, or unless such child or children are taught in a private school or at home in such branches as are usually taught in primary schools, or have already acquired the ordinary branches of learning taught in the public schools; provided, in case a public school shall not be taught for the period of twelve weeks, or any part thereof during the year, within two miles by the nearest traveled road of the residence of any person within the school district, he or she shall not be liable to the provisions of this Act.

Section 2. Any parent, guardian or other person having control or charge of any child or children failing to comply with the provisions of this Act shall be liable to a fine of not less than five dollars nor more than twenty-five dollars for the first offense, nor less than twenty-five dollars nor more than fifty dollars for the second and each subsequent offense, besides the cost of the prosecution.

Section 3. It shall be the duty of the directors and clerk of each school district to make diligent effort to see that this law is enforced in their respective districts.

Section 4. Justices of the peace shall have concurrent jurisdiction with the circuit court in all prosecutions under this Act.

Section 5. Inasmuch as many children are now permitted to remain away from school without cause and to their great detriment, this law shall take effect and be in force from and after its approval by the Governor.

Approved February 25, 1889.

Alabama's 1919 compulsory attendance law ${ }^{45}$

ARTICLE 15. SCHOOL ATTENDANCE.

Section 1. Every parent, guardian or other person in the State of Alabama having control or charge of any child or children between the ages of eight (8) and sixteen (16) years shall be required to send such child or children to a public school or to a private, denominational or parochial school, taught by a competent instructor, and such child or children shall attend school

\footnotetext{
${ }^{44} 1889$ Ore. Acts 111.

${ }^{45} 1919$ Ala. Acts 615.
} 
for the entire length of the school term in every scholastic year, provided that the county or city board of education, as the case may be, shall have power to reduce the period of compulsory attendance to not less than one hundred (100) days for any individual school, unless the school term for any school is less than one hundred (100) days, in which event the period of compulsory attendance shall be for the entire school term. The period of compulsory attendance shall commence at the beginning of the school, unless otherwise ordered by the county or city board of education, as the case may be, with the approval of the State board of education.

Section 2. Any child or children fourteen (14) years of age and upward, who have completed the elementary course of study or the equivalent thereof, or who are legally and regularly employed under the provisions of the Child Labor Law, ${ }^{46}$ shall be exempt from the provisions of this Article, and in case there be no public school within two and one-half miles by the nearest traveled road of any person between the ages of eight (8) and sixteen (16) years, he or she shall not be subject to the provisions of this article, unless public transportation within reason- able walking distance is provided.

Section 3. Any child or children who are physically or mentally incapacitated for the work of the school are exempt from this article, but the school authorities shall have the right, and they are hereby authorized, when exemptions under the provisions of this article are claimed by any parent, guardian or other person having control of any child or children, to require from a practicing physician a properly attested certificate, that such child or children should not be required to attend school for some physical or mental condition which renders attendance impracticable or inexpedient.

Sections 4-8 [describes duties of attendance officers]

Section 9. It shall be unlawful for any parent, guardian, or other person having control of a child to fail to send such child to school as required by the provisions of this article, and any parent, guardian, or other person violating the provisions of this article, shall be guilty of a misdemeanor, and shall be fined in a sum of not less than five (\$5) dollars, nor more than fifty (\$50.) dollars, and may be committed to the county jail for a term of not to exceed thirty (30) days. All fines collected shall be paid into the county or city treasury, as the case may be, and it is hereby made the duty of all city attorneys in their respective cities, and of all county and circuit solicitors for the respective counties and districts to prosecute all complaints filed and actions brought under this article.

Sections 10-15 [describes treatment of truants, state reporting, and school vacations]

\footnotetext{
${ }^{46}$ The child labor law of 1919 provided for legal employment at age 14 so long as the child had a fourth-grade education. 1919 Ala. Acts 867.
} 